OAK RIDGE

NATIONAL LABORATORY

MANAGED BY UT-BATTELLE

FOR THE DEPARTMENT OF ENERGY

\title{
Measurements of Mercury Released from Solidified/Stabilized Waste Forms
}

\section{April 2001}

C. $H$. Mattus

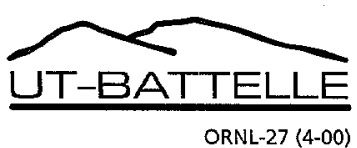




\title{
DOCUMENT AVAILABILITY
}

Reports produced after January 1, 1996, are generally available free via the U.S. Department of Energy (DOE) Information Bridge.

\section{Web site http://www.osti.gov/bridge}

Reports produced before January 1, 1996, may be purchased by members of the public from the following source.

\author{
National Technical Information Service \\ 5285 Port Royal Road \\ Springfield, VA 22161 \\ Telephone 703-605-6000 (1-800-553-6847) \\ TDD 703-487-4639 \\ Fax 703-605-6900 \\ E-mail info@ ntis.fedworld.gov \\ Web site http://www.ntis.gov/support/ordernowabout.htm
}

Reports are available to DOE employees, DOE contractors, Energy Technology Data Exchange (ETDE) representatives, and International Nuclear Information System (INIS) representatives from the following source.

Office of Scientific and Technical Information

P.O. Box 62

Oak Ridge, TN 37831

Telephone 865-576-8401

Fax 865-576-5728

E-mail reports@adonis.osti.gov

Web site http://www.osti.gov/contact.html

This report was prepared as an account of work sponsored by an agency of the United States Government. Neither the United States Government nor any agency thereof, nor any of their employees, makes any warranty, express or implied, or assumes any legal liability or responsibility for the accuracy, completeness, or usefulness of any information, apparatus, product, or process disclosed, or represents that its use would not infringe privately owned rights. Reference herein to any specific commercial product, process, or service by trade name, trademark, manufacturer, or otherwise, does not necessarily constitute or imply its endorsement, recommendation, or favoring by the United States Government or any agency thereof. The views and opinions of authors expressed herein do not necessarily state or reflect those of the United States Government or any agency thereof. 
Chemical Technology Division

\title{
MEASUREMENTS OF MERCURY RELEASED FROM SOLIDIFIED/STABILIZED WASTE FORMS
}

C. H. Mattus

April 2001

\author{
Prepared for the \\ U.S. Department of Energy \\ Office of Technology Development \\ Washington, D.C. 20585
}

\section{Prepared by}

OAK RIDGE NATIONAL LABORATORY

Oak Ridge, Tennessee 37831-6285

managed by

UT-BATTELLE, LLC

for the

U.S. DEPARTMENT OF ENERGY

under contract DE-AC05-00OR22725 


\section{CONTENTS}

LIST OF FIGURES $\ldots \ldots \ldots \ldots \ldots \ldots \ldots \ldots \ldots \ldots \ldots \ldots \ldots \ldots \ldots \ldots \ldots \ldots$

LIST OF TABLES $\ldots \ldots \ldots \ldots \ldots \ldots \ldots \ldots \ldots \ldots \ldots \ldots \ldots \ldots \ldots \ldots \ldots \ldots \ldots \ldots \ldots \ldots \ldots$

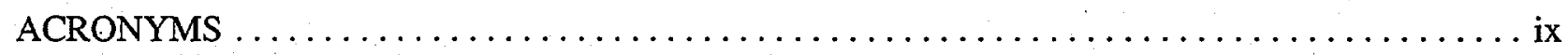

EXECUTIVE SUMMARY $\ldots \ldots \ldots \ldots \ldots \ldots \ldots \ldots \ldots \ldots \ldots \ldots \ldots \ldots \ldots \ldots \ldots \ldots \ldots$

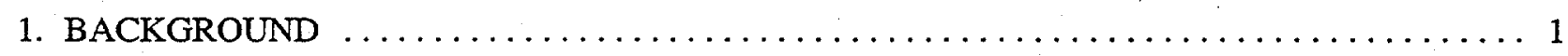

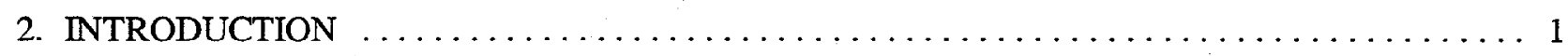

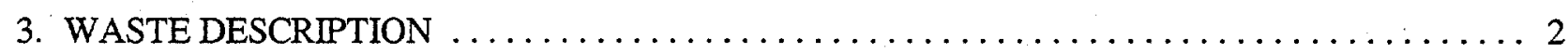

4. EQUIPMENT DESIGN - MERCURY VAPOR ANALYZER $\ldots \ldots \ldots \ldots \ldots \ldots \ldots \ldots$

5. MEASUREMENTS OF MERCURY RELEASE $\ldots \ldots \ldots \ldots \ldots \ldots \ldots \ldots \ldots \ldots \ldots \ldots \ldots$

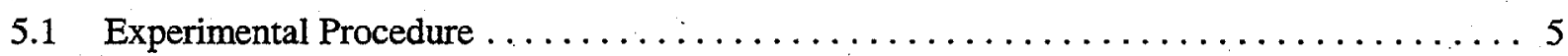

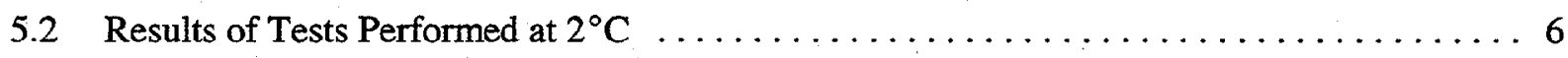

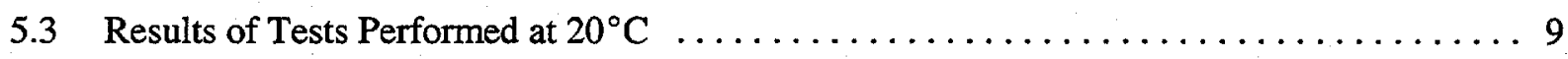

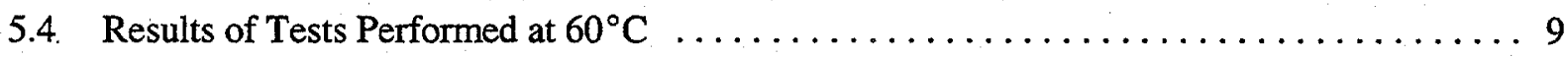

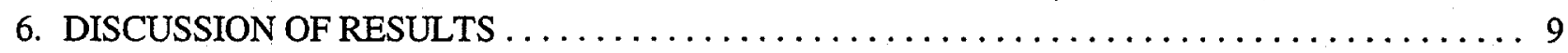

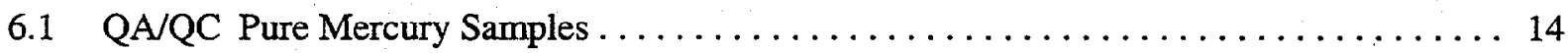

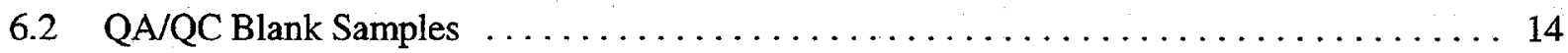

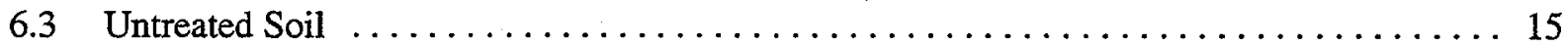

6.4 Thermal Desorption - SepraDyne Process $\ldots \ldots \ldots \ldots \ldots \ldots \ldots \ldots \ldots \ldots \ldots$

6.5 Solidification/Stabilization Using Sulfur Polymer Cement - BNL Process . . . . . . 15

6.6. Solidification/Stabilization Using Portland Cement-Based Additives - ATG Process . . 16

6.7 Solidification/Stabilization Using Proprietary Additives — NFS Process . . . . . . . 16

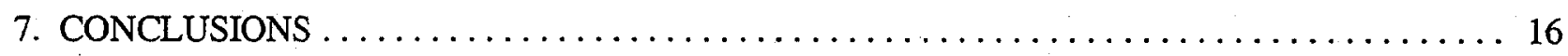

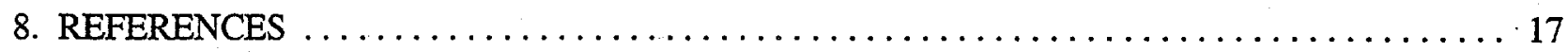

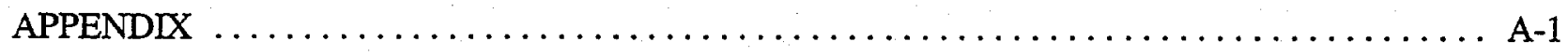


2

- 


\section{LIST OF FIGURES}

Figure

Page

1 Mercury concentration in headspace at $2^{\circ} \mathrm{C}$ - samples with lower concentrations ........ 7

2 Mercury concentration in headspace at $2^{\circ} \mathrm{C}$ - samples with higher concentrations ....... 8

3 Mercury concentration in headspace at $20^{\circ} \mathrm{C}$ - samples with lower concentrations . . . . . 10

4 Mercury concentration in headspace at $20^{\circ} \mathrm{C}$ - samples with higher concentrations ....... 11

5 Mercury concentration in headspace at $60^{\circ} \mathrm{C}$ - samples with lower concentrations ........ 12

6 Mercury concentration in headspace at $60^{\circ} \mathrm{C}$ - samples with higher concentrations ...... 13 


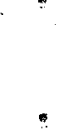

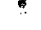




\section{LIST OF TABLES}

Table Page

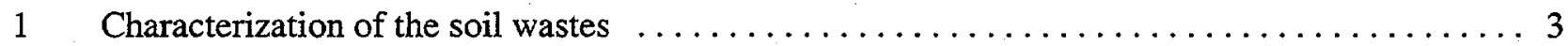

2 Summary of technologies and soils used for demonstrations $\ldots \ldots \ldots \ldots \ldots \ldots \ldots \ldots$

3 Mercury concentrations in samples and in TCLP extracts $\ldots \ldots \ldots \ldots \ldots \ldots \ldots \ldots \ldots$

4 Vapor concentration of pure mercury over the temperature range investigated $\ldots \ldots \ldots \ldots$

5 Instrument sensitivity as a function of the volume analyzed $\ldots \ldots \ldots \ldots \ldots \ldots \ldots \ldots$

A-1 Summary of data for the samples maintained at $2^{\circ} \mathrm{C} \ldots \ldots \ldots \ldots \ldots \ldots \ldots \ldots \ldots$

A-2 Summary of data for the samples maintained at $20^{\circ} \mathrm{C} \ldots \ldots \ldots \ldots \ldots \ldots \ldots \ldots \ldots$

A-3 Summary of data for the samples maintained at $60^{\circ} \mathrm{C} \ldots \ldots \ldots \ldots \ldots \ldots \ldots \ldots \ldots$ 


\section{ACRONYMS}

$\begin{array}{ll}\text { AMLGM } & \text { amalgamation } \\ \text { ASTM } & \text { American Society for Testing and Materials } \\ \text { ATG } & \text { Allied Technology Group } \\ \text { BNL } & \text { Brookhaven National Laboratory } \\ \text { CAA } & \text { Clean Air Act } \\ \text { CVAA } & \text { cold vapor atomic absorption } \\ \text { DOE } & \text { U.S. Department of Energy } \\ \text { EPA } & \text { U.S. Environmental Protection Agency } \\ \text { IMERC } & \text { incineration of mercury wastes } \\ \text { INEEL } & \text { Idaho National Engineering and Environmental Laboratory } \\ \text { LDR } & \text { Land Disposal Restrictions } \\ \text { MLLW } & \text { mixed low-level waste } \\ \text { MWFA } & \text { Mixed Waste Focus Area } \\ \text { NFS } & \text { Nuclear Fuel Services } \\ \text { ORNL } & \text { Oak Ridge National Laboratory } \\ \text { ppb } & \text { parts per billion } \\ \text { ppm } & \text { parts per million } \\ \text { RCRA } & \text { Resource Conservation and Recovery Act } \\ \text { RMERC } & \text { retorting or roasting of mercury wastes } \\ \text { SPC } & \text { sulfur polymer cement } \\ \text { S/S } & \text { solidification/stabilization } \\ \text { TCLP } & \text { Toxicity Characteristic Leaching Procedure } \\ \text { TLV } & \text { Threshold Limiting Value } \\ \text { UTS } & \text { Universal Treatment Standards } \\ & \end{array}$





\section{EXECUTIVE SUMMARY}

This report covers work performed during FY 1999-2000 in support of treatment demonstrations conducted for the Mercury Working Group of the U.S. Department of Energy (DOE) Mixed Waste Focus Area. In order to comply with the requirements of the Resource Conservation and Recovery Act, as implemented by the U.S. Environmental Protection Agency (EPA), DOE must use one of these procedures for wastes containing mercury at levels above $260 \mathrm{ppm}$ : a retorting/roasting treatment or an incineration treatment (if the wastes also contain organics). The recovered radioactively contaminated mercury must then be treated by an amalgamation process prior to disposal. The DOE Mixed Waste Focus Area and Mercury Working Group are working with the EPA to determine if some alternative processes could treat these types of waste directly, thereby avoiding for DOE the costly recovery step. They sponsored a demonstration in which commercial vendors applied their technologies for the treatment of two contaminated waste soils from Brookhaven National Laboratory. Each soil was contaminated with 4500 ppm mercury; however, one soil had as a major radioelement americium-241, while the other contained mostly europium-152. The project described in this report addressed the need for data on the mercury vapor - released by the solidified/stabilized mixed low-level mercury wastes generated during these demonstrations as well as the comparison between the untreated and treated soils. A related work began in FY 1998, with the measurement of the mercury released by amalgamated mercury, and the results were reported in ORNL/TM-13728.

Four treatments were performed on these soils. The baseline was obtained by thermal treatment performed by SepraDyne Corp., and three forms of solidification/stabilization were employed: one using sulfur polymer cement (Brookhaven National Laboratory), one using portland cement [Allied Technology Group (ATG)], and a third using proprietary additives (Nuclear Fuel Services).

The release of mercury vapor above the headspace of the untreated soils and waste forms was studied as a function of temperature. Three temperatures were selected: $2,20-22$, and $60^{\circ} \mathrm{C}$. Measurements were performed at three time intervals - 1,3, and 7 days - to ensure that equilibrium between the solid and gas phases had been achieved.

Results showed that untreated soil containing either radionuclide (americium or europium) released mercury vapor in the headspace in the same way that pure mercury was released. During the tests, some tiny droplets of elemental mercury were observed in the soil, which corroborates the measurements obtained. The soil treated by either process (thermal desorption or solidification/stabilization) released little mercury vapor in the headspace, up to a factor of 350 less when compared with the untreated soils. At $20^{\circ} \mathrm{C}$, the soil stabilized by ATG released the most mercury, at levels slightly above the threshold limiting value (TLV) of $0.05 \mathrm{mg} / \mathrm{m}^{3}$, with quantities varying between 0.04 and $0.11 \mathrm{mg} / \mathrm{m}^{3}$. The other treated soils were found to be comparable with the thermal desorption process. However, it should be noted that because of the sensitivity of the instrument and the small volumes analyzed, a direct comparison of the results with the TLV is not appropriate.

At $60^{\circ} \mathrm{C}$ the same sample treated by ATG released between 1 and $3 \mathrm{mg} / \mathrm{m}^{3}$ of mercury, while the levels for the others were below $0.5 \mathrm{mg} / \mathrm{m}^{3}$. These values should be compared with the releases measured in the untreated soils, which ranged from 100 to $\sim 180 \mathrm{mg} / \mathrm{m}^{3}$. 



\section{BACKGROUND}

Significant quantities of waste containing both radioactive components and mercury [mixed low-level waste (MLLW)] are currently stored at several U.S. Department of Energy (DOE) facilities. In order to meet U.S. Environmental Protection Agency (EPA) Land Disposal Restrictions (LDR), the treatment standard for this type of waste under the Resource Conservation and Recovery Act (RCRA), as set forth in 40 CFR 268.40 , is amalgamation. For radioactively contaminated wastes containing mercury at levels above 260 $\mathrm{ppm}$, one of two treatment standards is currently applied. If the waste does not contain organic constituents, retorting or roasting in a thermal processing unit is the treatment standard to follow; if the waste also contains organics, then incineration is the approved treatment standard. Recovery of the radioactive mercury is then followed by an amalgamation step before final disposal can occur. In an effort to reduce the costs associated with this two-step treatment, the Mixed Waste Focus Area (MFWA) and the Mercury Working Group are working together with the EPA to determine whether some form of direct treatment would meet the goal of a maximum TCLP extract concentration of $0.025 \mathrm{mg} / \mathrm{L}$ mercury while also reducing the cost for final disposal of these wastes.

Recently, concerns have arisen about the release of mercury vapors from amalgamated or stabilized wastes. Much work was done to stabilize/amalgamate the mercury, and success was declared when the leaching results were found to be satisfactory. However, no measurement of the headspace of the waste forms was performed and the possibility for volatilization of the mercury was overlooked. In the work performed in FY 1999 for the Mercury Working Group, the author of this report measured significant amounts of mercury vapors released by some amalgams prepared by commercial vendors (1). Hamilton and Bowers have studied the release of mercury vapors from solidified/stabilized waste forms using portland cement as a matrix (2). Their findings corroborate the author's: the concentration of mercury in the vapors increased with temperature and time when oxide or elemental mercury species were involved. The mercury was released quickly, and the headspace above the samples became saturated within a few hours. When mercury was stabilized with sulfide, no release of mercury vapor was measured.

Recently, in reporting to Congress, the R\&D Mercury Group from the Florida landfill wrote that "the working face of the landfill may be more important than the landfill gas as a source of mercury emissions. While most of the mercury buried within the landfill may be immobilized, operations on the working face lead to emissions as mercury-containing devices break. Moreover, the study found that landfills may emit highly toxic organic.mercury, as the result of reactions that take place within the landfill" (3).

\section{INTRODUCTION}

One of the primary performance requirements specified in the MWFA Technology Development Requirements Document - Mercury Amalgamation - is related to vapor emissions: "The process must not release mercury vapors into the environment above the limits established by the applicable air permit [in accordance with Clean Air Act (CAA) requirements]. In addition, the process should not expose 
operators to mercury vapors above the established Threshold Limiting Value (TLV) of $0.05 \mathrm{mg} / \mathrm{m}^{3}$. Using the TLV as a basis, the final waste form must have a vapor pressure of less than $10^{-6}$ torr at $140^{\circ} \mathrm{F} "(4)$.

"Vapor pressure" is defined as the pressure at which a liquid or solid is in equilibrium with its vapor at a given temperature (5). This property depends only upon the temperature and the composition of the material considered. For a typical liquid, a constant and reproducible vapor pressure exists, which varies only with the temperature (i.e., it increases as the temperature rises).

The modified test procedure used in this study was very similar to the static headspace analysis method used by Kriger and Turner (6). In this technique, the mercury vapor pressure was allowed to reach equilibrium in a static headspace and the mercury concentration (mass/volume) in the headspace was subsequently measured using a commercial mercury vapor analyzer. This instrument was used successfully in the work performed during FY 1999 (1) and was also used by other scientists for similar work $(2,6)$.

\section{WASTE DESCRIPTION}

Two soil wastes stored at Brookhaven National Laboratory (BNL) on Long Island, New York, were used in this demonstration. These soils contained about $4500 \mathrm{mg} / \mathrm{kg}$ mercury and were also contaminated with radionuclides - americium-241 in one case and europium-152 in the other. For each soil, four drums were sampled and analyzed for radionuclide content, total mercury, and leachable mercury via the Toxicity Characteristic Leaching Procedure (TCLP). Characterization of these two soils was performed at BNL, and data are provided in Table 1.

The vendors - BNL, SepraDyne, Allied Technology Group (ATG), and Nuclear Fuel Services (NFS) provided samples of the untreated soil they received as well as the treated soil they generated via the application of their processes. The untreated soil appeared to be a sand-like material with some large pebbles and pieces of debris. Some vendors received only one type of soil for their demonstration, while others received both soils. Table 2 summarizes the technology as well as the type of soil used for each demonstration.

These samples will be used to test a new set of protocols developed by Dr. David Kosson at Vanderbilt University. This set of protocols, which could replace the controversial TCLP in the future, requires that particles in the sample be reduced in size to $\leq 300 \mu \mathrm{m}, \leq 2 \mathrm{~mm}$, or $\leq 5 \mathrm{~mm}$. For our project, based on the size of the untreated soil material, we chose a maximum size of $\leq 2 \mathrm{~mm}$. All the samples were crushed if necessary and sieved. The sieved samples were then used for the mercury vapor measurement test. 
Table 1. Characterization of the soil wastes

\begin{tabular}{lccccccccccc}
\hline & \multicolumn{4}{c}{ Soil contaminated with } & curopium-152 & \multicolumn{3}{c}{ Soil contaminated with americium-241 } \\
\cline { 2 - 12 } & E-1 & E-2 & E-3 & E-4 & Average & A-1 & A-2 & A-3 & A-4 & Average \\
\hline Am-241(pCi/g) & 0 & 0 & 0 & 0 & $\mathbf{0}$ & 12,230 & 9,085 & 12,130 & 17,160 & $\mathbf{1 2 , 6 5 1}$ \\
Cs-137 (pCi/g) & 14.1 & 13.39 & 17.38 & 13.39 & $\mathbf{1 4 . 5 7}$ & $\mathbf{0 . 1 2 5 7}$ & 0.0709 & 0.1736 & 0.3673 & $\mathbf{0 . 1 8 4 4}$ \\
Gross alpha (pCi/g) & 327 & 714 & 345 & 584 & $\mathbf{4 9 3}$ & 5150 & 16,317 & 8467 & 15,795 & $\mathbf{1 1 , 4 3 2}$ \\
Gross beta (pCi/g) & 187 & 306 & 210 & 377 & $\mathbf{2 7 0}$ & 386 & 1114 & 768 & 1586 & $\mathbf{9 6 4}$ \\
Eu-152 (pCi/g) & 20.73 & 15.29 & 36.56 & 7.625 & $\mathbf{2 0 . 0 5}$ & & & & & \\
Eu-154 (pCi/g) & 14.09 & 10.52 & 20.76 & 5.953 & $\mathbf{1 2 . 8 3}$ & & & & & \\
Pu-238 (pCi/g) & 0 & 0 & 0 & 0 & $\mathbf{0}$ & 6.41 & 4.8 & 4.91 & 16.7 & $\mathbf{8 . 2 1}$ \\
Pu-239/240 (pCi/g) & 0.279 & 0.375 & 0.188 & 0.259 & $\mathbf{0 . 2 8}$ & 29.3 & 15.3 & 17.1 & 56.8 & $\mathbf{2 9 . 6 3}$ \\
U-234 (pCi/g) & 14.4 & 14 & 11.4 & 17.4 & $\mathbf{1 4 . 3}$ & 0.35 & 0.232 & 0.344 & 0.502 & $\mathbf{0 . 3 5 7}$ \\
U-235 (pCi/g) & 0.66 & 0.774 & 0.562 & 0.773 & $\mathbf{0 . 6 9 2}$ & 0.023 & 0.045 & 0.0125 & 0.0197 & $\mathbf{0 . 0 2 5 1}$ \\
U-238 (pCi/g) & 11.7 & 11.7 & 9.21 & 14.6 & $\mathbf{1 1 . 8 0}$ & 0.23 & 0.181 & 0.166 & $\mathbf{0 . 2 2 9}$ & $\mathbf{0 . 2 0 2}$ \\
\hline TCLP (mg/L) & & & & & & & & & & \\
Barium & 1.56 & 1.78 & 1.48 & 1.82 & $\mathbf{1 . 6 6 0}$ & 0.134 & 0.193 & 0.357 & $\mathbf{0 . 1 5}$ & $\mathbf{0 . 2 0 9}$ \\
Mercury & 0.208 & $\mathbf{0 . 2 4 5}$ & 0.191 & $\mathbf{0 . 2 1 2}$ & $\mathbf{0 . 2 1 4}$ & 0.868 & 1.5 & 1.39 & 1 & $\mathbf{1 . 1 9 0}$ \\
Cadmium & $\mathbf{0 . 1 6 4}$ & 0.116 & 0.0999 & 0.148 & $\mathbf{0 . 1 3 2}$ & 0 & 0 & 0 & 0 & $\mathbf{0 . 0 0 0}$ \\
Lead & 0.754 & 0.789 & 0.736 & 0.993 & $\mathbf{0 . 8 1 8}$ & $<0.015$ & 0.0216 & 0.0263 & $<0.015$ & $\mathbf{0 . 0 2 4}$ \\
\hline Mercury (mg/kg) & 4,190 & 3,100 & 4,880 & 5,510 & $\mathbf{4 , 4 2 0}$ & 4,040 & 4,190 & 2,310 & 5,570 & $\mathbf{4 , 0 2 8}$ \\
\hline
\end{tabular}

Table 2. Summary of technologies and soils used for demonstrations

\begin{tabular}{ccc}
\hline Vendor & Technology & Soil used \\
\hline BNL & Sulfur polymer cement & Am-241 \\
SepraDyne & Thermal treatment & Am -241 and Eu-152 \\
ATG & Solidification/stabilization & Eu-152 \\
NFS & Solidification/stabilization & Am-241 \\
\hline
\end{tabular}

Each sample received was analyzed by cold vapor atomic absorption (CVAA) for total mercury concentration. The instrument used was a PS200 from Lehman Labs. The sample preparation and analysis were conducted according to EPA method SW846-7471. A modified TCLP test was performed on each sample following SW846-1311, using only $20 \mathrm{~g}$ of sample and $400 \mathrm{~mL}$ of extraction fluid instead of the $100 \mathrm{~g} / 2 \mathrm{~L}$ indicated in Method 1311. The extracts were then analyzed by CVAA for mercury. The results of both the total mercury concentration present in the sample and the mercury extracted in the TCLP test are provided in Table 3. Data provided by the vendor, when available, are shown in bold character. 
Table 3. Mercury concentrations in samples and in TCLP extracts

\begin{tabular}{|c|c|c|}
\hline Sample & $\begin{array}{c}\text { Mercury concentration } \\
\qquad(\mathrm{mg} / \mathrm{kg})\end{array}$ & $\begin{array}{l}\text { Mercury in modified } \\
\text { TCLP }(\mu \mathrm{g} / \mathrm{L})\end{array}$ \\
\hline Untreated soil $(\mathrm{Eu})$ received from ATG & 5,$480 ; 4,200$ & $105 ; 282$ \\
\hline Untreated soil (Eu) received from $B N L$ & 3,250 & 78.7 \\
\hline Untreated soil (Am) received from NFS & 3,470 & 270 \\
\hline Untreated soil (Am) received from BNL & 3,280 & 401 \\
\hline SepraDyne thermal treatment - soil Eu & 1.39 & 0.005 \\
\hline SepraDyne thermal treatment - soil Am & 4.53 & 3.33 \\
\hline BNL sulfur polymer cement - soil Am & 997 & 42.7 \\
\hline ATG solidification/stabilization - soil Eu & 1,840 & $32.9 ; 2.03$ to $13.9^{a}$ \\
\hline NFS solidification/stabilization - soil Am & 2,410 & 3.0 \\
\hline Regulatory limit of mercury in TCLP & & 200 \\
\hline UTS limit for mercury & & 25 \\
\hline
\end{tabular}

\section{EQUIPMENT DESIGN - MERCURY VAPOR ANALYZER}

The instrument used for measurement of the vapor pressure of mercury was a Jerome 431-X gold-film mercury vapor analyzer from Arizona Instruments (Phoenix, Arizona). The range of detection is 0.000 to $0.999 \mathrm{mg} / \mathrm{m}^{3}$ mercury. The sensitivity of the instrument is $0.003 \mathrm{mg} / \mathrm{m}^{3}$, well below the TLV of $0.05 \mathrm{mg} / \mathrm{m}^{3}$. The air sampling is performed with the aid of an internal pump. The amount of air sampled and analyzed each time is $87.5 \mathrm{~mL}$. The air flows through a guard column packed with soda lime for removing moisture and acid gases. The resulting dry vapor is deposited onto a gold film, which forms an amalgam with mercury, thus increasing the electrical resistance of the film. This instrument is stable and selective for mercury and, unlike ultraviolet analyzers, is not prone to interferences such as those from water vapor and hydrocarbons. When the sensor approaches its saturation limit, the instrument provides a warning; regeneration of the sensor then takes about $10 \mathrm{~min}$. The instrument should not be used for about $30 \mathrm{~min}$ after regeneration of the sensor to allow the metal to cool down to room temperature.

\section{MEASUREMENTS OF MERCURY RELEASE}

The objective of this set of experiments was to study the effect of temperature on the mercury vapors released from the various waste forms and untreated soils. Measurements were made at the following temperatures: $2^{\circ} \mathrm{C}$, ambient $\left(-20-22^{\circ} \mathrm{C}\right)$, and $60^{\circ} \mathrm{C}$.

The objective of these tests was to measure the release of elemental mercury vapor over a given set of conditions for each candidate waste form and to compare the results with those for pure elemental mercury. In the literature, the mercury vapor pressure above pure mercury is expressed as a function of temperature. The expected gas space concentration of mercury at each temperature can be calculated 
from the mercury partial pressure using the ideal gas law, Eq. (1). The calculated data are presented in Table 4.

$$
\frac{w}{v}=\frac{p M}{R T}
$$

where

$$
\begin{aligned}
& p=\text { vapor pressure of the sample }(\mathrm{Pa}) \\
& w=\text { mass of vaporized material }(\mathrm{g}) \\
& M=\text { molecular weight of mercury }\left(\mathrm{g} \cdot \mathrm{mol}^{-1}\right) \\
& \mathrm{R}=\text { gas constant }\left(8.31 \mathrm{~Pa} \cdot \mathrm{m}^{3} \cdot \mathrm{mol}^{-1} \cdot \mathrm{K}^{-1}\right) \\
& T=\text { temperature }(\mathrm{K}) \\
& v=\text { volume analyzed }\left(\mathrm{m}^{3}\right)
\end{aligned}
$$

\begin{tabular}{|c|c|c|c|c|c|c|c|c|c|c|c|c|c|}
\hline $\begin{array}{c}\mathrm{T} \\
\left({ }^{\circ} \mathrm{C}\right)\end{array}$ & $\begin{array}{l}{[\mathrm{Hg}]} \\
\left(\mathrm{mg} / \mathrm{m}^{3}\right)\end{array}$ & $\begin{array}{c}T \\
\left({ }^{\circ} \mathrm{C}\right)\end{array}$ & $\begin{array}{l}{[\mathrm{Hg}]} \\
\left(\mathbf{m g} / \mathrm{m}^{3}\right)\end{array}$ & $\begin{array}{c}T \\
\left({ }^{\circ} \mathrm{O}\right)\end{array}$ & $\begin{array}{l}{[\mathrm{Hg}]} \\
\left(\mathrm{mg} / \mathrm{m}^{3}\right)\end{array}$ & $\begin{array}{c}\mathbf{T} \\
\left({ }^{\circ} \mathrm{C}\right)\end{array}$ & $\begin{array}{l}{[\mathrm{Hg}]} \\
\left(\mathrm{mg} / \mathrm{m}^{3}\right)\end{array}$ & $\begin{array}{c}\mathrm{T} \\
\left({ }^{\circ} \mathrm{C}\right)\end{array}$ & $\begin{array}{l}{[\mathrm{Hg}]} \\
\left(\mathrm{mg} / \mathrm{m}^{3}\right)\end{array}$ & $\begin{array}{c}\mathbf{T} \\
\left({ }^{\circ} \mathrm{C}\right)\end{array}$ & $\begin{array}{l}{[\mathbf{H g}]} \\
\left(\mathrm{mg} / \mathrm{m}^{3}\right)\end{array}$ & $\begin{array}{c}T \\
\left({ }^{\circ} \mathrm{C}\right)\end{array}$ & $\begin{array}{l}{[\mathrm{Hg}]} \\
\left(\mathrm{mg} / \mathrm{m}^{3}\right)\end{array}$ \\
\hline 1 & 2.42 & 11 & 6.10 & 21 & 14.37 & 31 & 31.93 & 41 & 67.32 & 51 & 135.28 & 61 & 260.30 \\
\hline 2 & 2.67 & 12 & 6.63 & 22 & 15.54 & 32 & 34.38 & 42 & 72.15 & 52 & 144.37 & 62 & 276.76 \\
\hline 3 & 2.94 & 13 & 7.27 & 23 & 16.93 & 33 & 37.22 & 43 & 77.68 & 53 & 154.68 & 63 & 295.27 \\
\hline 4 & 3.20 & 14 & 7.91 & 24 & 18.31 & 34 & 40.04 & 44 & 83.18 & 54 & 164.92 & 64 & 313.67 \\
\hline 5 & 3.53 & 15 & 8.66 & 25 & 19.91 & 35 & 43.30 & 45 & 89.48 & 55 & 176.58 & 65 & 334.29 \\
\hline 6 & 3.86 & 16 & 9.41 & 26 & 21.51 & 36 & 46.53 & 46 & 95.74 & 56 & 188.16 & 66 & 354.79 \\
\hline 7 & 4.25 & 17 & 10.28 & 27 & 23.36 & 37 & 50.26 & 47 & 102.89 & 57 & 201.28 & 67 & 377.92 \\
\hline 8 & 4.65 & 18 & 11.15 & 28 & 25.20 & 38 & 53.96 & 48 & 110.00 & 58 & 214.33 & 68 & 400.91 \\
\hline 9 & 5.11 & 19 & 12.17 & 29 & 27.34 & 39 & 58.22 & 49 & 118.10 & 59 & 229.08 & 69 & 426.72 \\
\hline 10 & 5.57 & 20 & 13.18 & 30 & 29.47 & 40 & 62.46 & 50 & 126.14 & 60 & 243.75 & 70 & 452.39 \\
\hline
\end{tabular}

Table 4. Vapor concentration of pure mercury over the temperature range investigated ${ }^{a}$

${ }^{\mathrm{a}}$ Derived from CRC Handbook of Chemistry and Physics, 47th edition, p. D-108.

\subsection{Experimental Procedure}

The sample preparation was performed using $\mathrm{Kapak}^{\circledR}$ pouches and glass sample vials with Teflon septa. The samples to be maintained at 2 and $20^{\circ} \mathrm{C}$ were introduced into the pouches, while those to be tested at $60^{\circ} \mathrm{C}$ were placed in glass vials. The samples at $0-3^{\circ} \mathrm{C}$ were placed in a container filled with ice and water and stored in a refrigerator set at $2^{\circ} \mathrm{C}$. A thermocouple was placed in the liquid to measure the temperature of the bath where the samples were sitting. Tests made during FY 1999 showed that the samples could not simply remain in the refrigerator, since opening the door modified the temperature and thus introduced variations in the measurements. The samples at $20-22^{\circ} \mathrm{C}$ were maintained at room temperature in the laboratory using a thermocouple to monitor the temperature. The samples tested at $60^{\circ} \mathrm{C}$ were placed in a water bath to avoid fluctuation of temperature during sampling. The temperature of the water was monitored using equipment with a digital readout. Since the release of mercury in the headspace is independent of the amount of sample present, approximately $15 \mathrm{~mL}$ of material (equivalent 
to a tablespoon) was introduced into each bag or vial. The samples were not dried prior to testing. The bags were then filled with compressed air to provide the necessary volume needed for later sampling (and to allow for volume changes during the curing time), heat sealed, and transferred into their respective locations for curing. All the samples were prepared in triplicate. For each temperature, as a means of ensuring quality, a blank and a sample containing pure mercury metal served as controls and were also run in triplicate. At selected time intervals, the samples were measured; then the bags were resealed.

Volumes of 0.2 to $10 \mathrm{~mL}$ of the headspace sample diluted to a total of $87.5 \mathrm{~mL}$ by room air were found to be appropriate for use in this set of experiments. The total concentration had to be recalculated to take into account the dilution made during sampling. Even though equilibrium between the sample and the air above is reached rapidly (2), measurements were made at 1,3 , and 7 days to confirm that the data obtained were representative of an equilibrium condition.

Each bag was sampled and analyzed four times, and the results were averaged. The standard deviation for the 12 measurements made for each sample was used in calculating the error on the average concentration. The plots are bar graphs where the average concentration is represented in bold and the range of possible concentration is represented as a line on each side of the average. The large difference in mercury concentration among the samples did not allow adequate representation of the data on one plot in that the samples showing a low release of mercury would not have been differentiated. Therefore, two plots are presented for each temperature-one representing the samples with low release of mercury, and the other representing the samples releasing larger amounts of mercury.

Because some treated samples were unavailable in May when the first test was performed, another series of tests was conducted in September. Each time the same QA/QC samples were measured with the samples, which explained the presence of the blank and two mercury standards. The thermal treatment samples from SepraDyne are associated with the blank and mercury standard A and were run in May. The three other treated soils - sulfur polymer cement by BNL, solidification and stablization by ATG, and solidification and stabilization by NFS - were run in September and are associated with the blank and mercury standard $\mathrm{B}$.

\subsection{Results of Tests Performed at $2^{\circ} \mathrm{C}$}

After 1,3, and 7 days, a series of measurements was performed. The data obtained are summarized in the appendix (Table A.1); and Figs. 1 and 2 plot the average values obtained for each series as well as the domain of error associated with the measurements. 


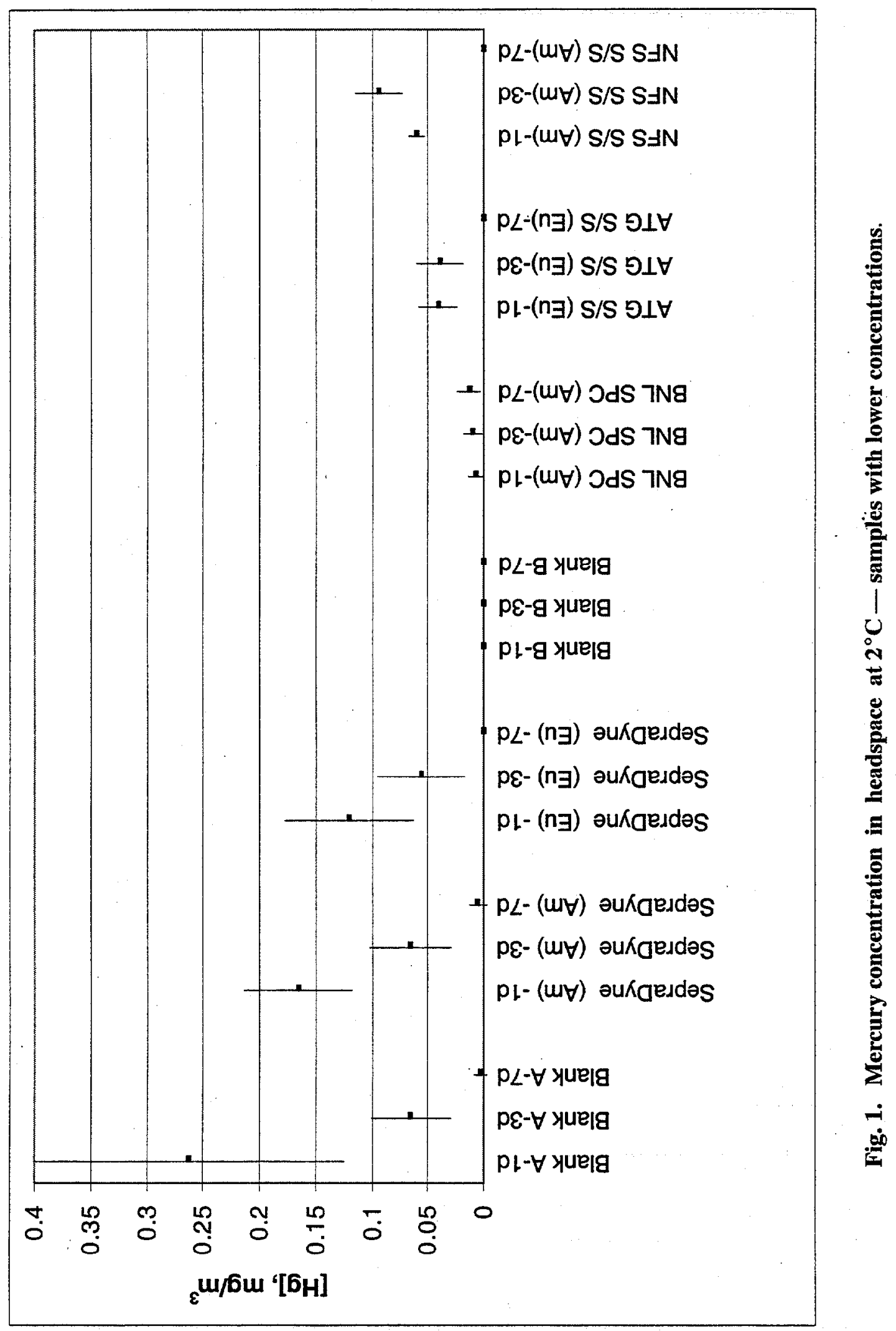




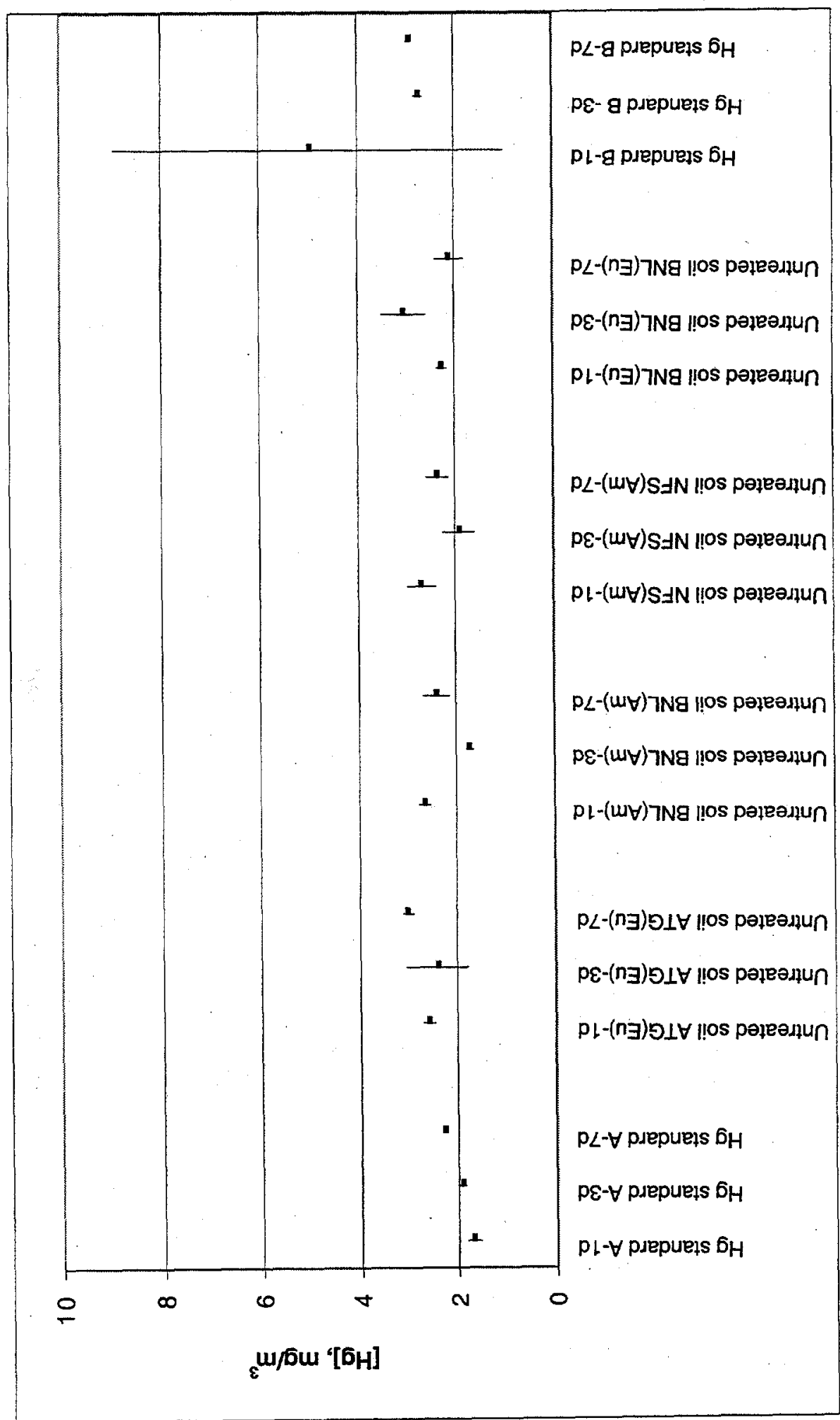

 


\subsection{Results of Tests Performed at $20^{\circ} \mathrm{C}$}

The samples were maintained at room temperature $\left(\sim 21.5^{\circ} \mathrm{C}\right)$ for this set of experiments. The data obtained at 1,3, and 7 days are summarized in Table A.2 of the appendix. Figures 3 and 4 plot the average values obtained for each series.

\subsection{Results of Tests Performed at $60^{\circ} \mathrm{C}$}

For this series of tests, the data showed more fluctuation than for the two other temperatures. Opening the water bath probably caused the temperature of the samples to drop; furthermore, the smaller volume of air sampled introduced a larger error in the mercury concentration measured. The data obtained are compiled in Table A-3 of the appendix and illustrated in Figs. 5 and 6.

\section{DISCUSSION OF RESULTS}

Some parameters in these experiments were not controlled closely enough, thus providing only semiquantitative results that could not be used to determine if a waste form was actually at or below the TLV concentration. Some of the samples were actually tested a long time after the treatment was completed, with the storage of the samples being uncontrolled during that time. The samples were size reduced to fit the experiment and may not represent the actual waste form in its definitive form. In order to accurately determine the concentration of mercury, larger volumes of air should be sampled. However, this would not be compatible with the experiment in the laboratory, which would require regeneration of the sensor after each measurement when using the mercury vapor analyzer supplied by Arizona Instruments. If a measurement was needed to compare the mercury released by the waste form with the TLV, it should be done on the actual waste form - monolith or not - after completion of the process. The waste form should also be maintained under controlled conditions - temperature, humidity, time - until the measurement is performed.

In this study, the results obtained at room temperature are probably the most accurate and reproducible since there was little fluctuation in temperature during the measurements. Sample volumes of $0.2-10 \mathrm{~mL}$ were used for the experiments. The error in the measured volume was estimated to be in the range of $20-25 \%$ for the smaller volumes and $\sim 5 \%$ for the higher volumes analyzed.

As discussed in Sect. 4, the mercury vapor analyzer is sensitive to within $0.003 \mathrm{mg} / \mathrm{m}^{3}$. This value needs to be corrected by the dilution factor; the resulting sensitivities for each volume analyzed are shown in Table 5. During the early phase of testing, smaller volumes were removed and analyzed without realizing that the sensitivity of the instrument suffered, as shown in Table 5. In subsequent tests, larger volumes were used to eliminate the issue of sensitivity. As a result, data associated with early measurements are higher than those in which larger volumes were used, making some data comparisons difficult. 


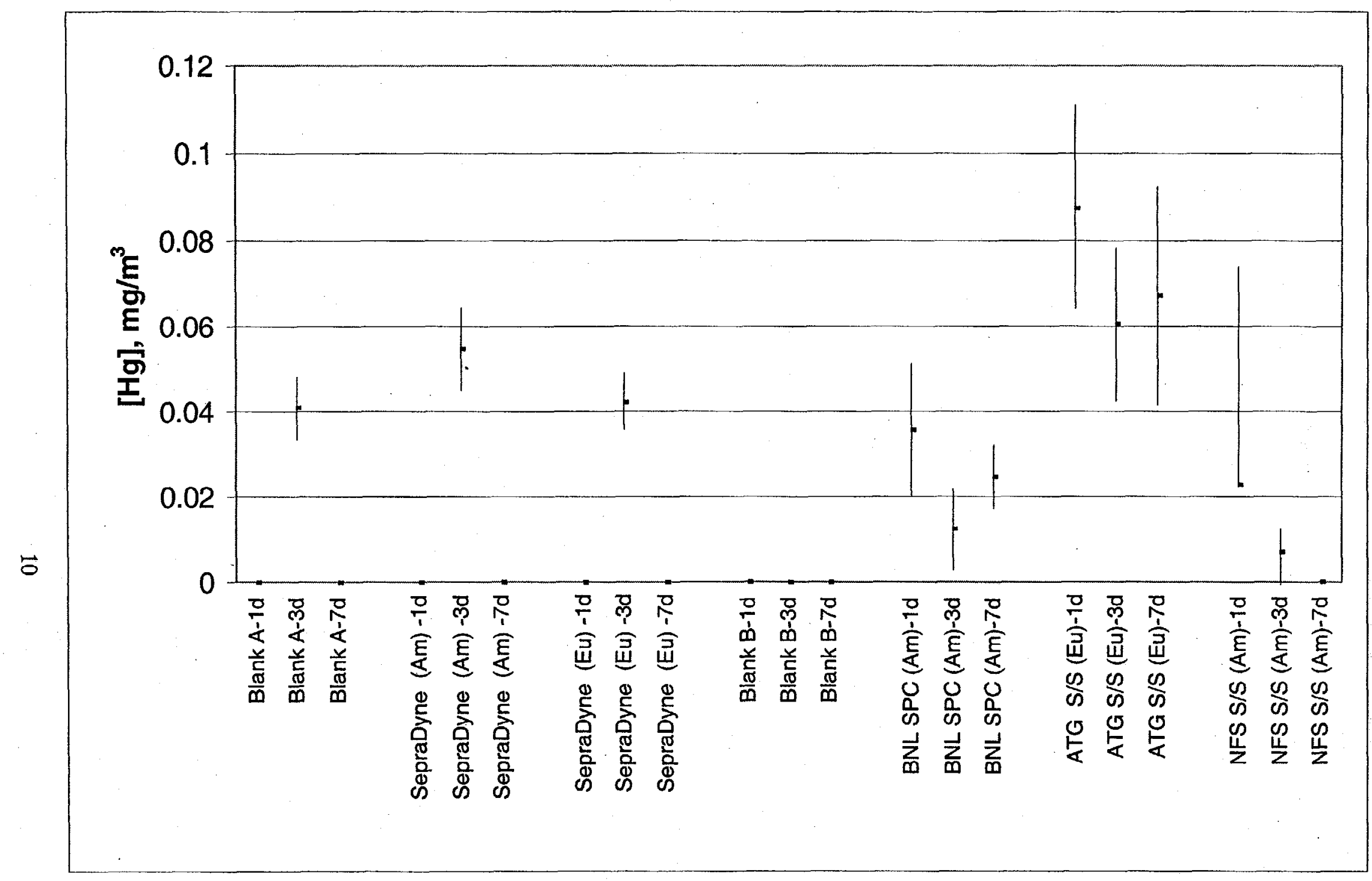

Fig. 3. Mercury concentration in headspace at $20^{\circ} \mathrm{C}$-samples with lower concentrations. 


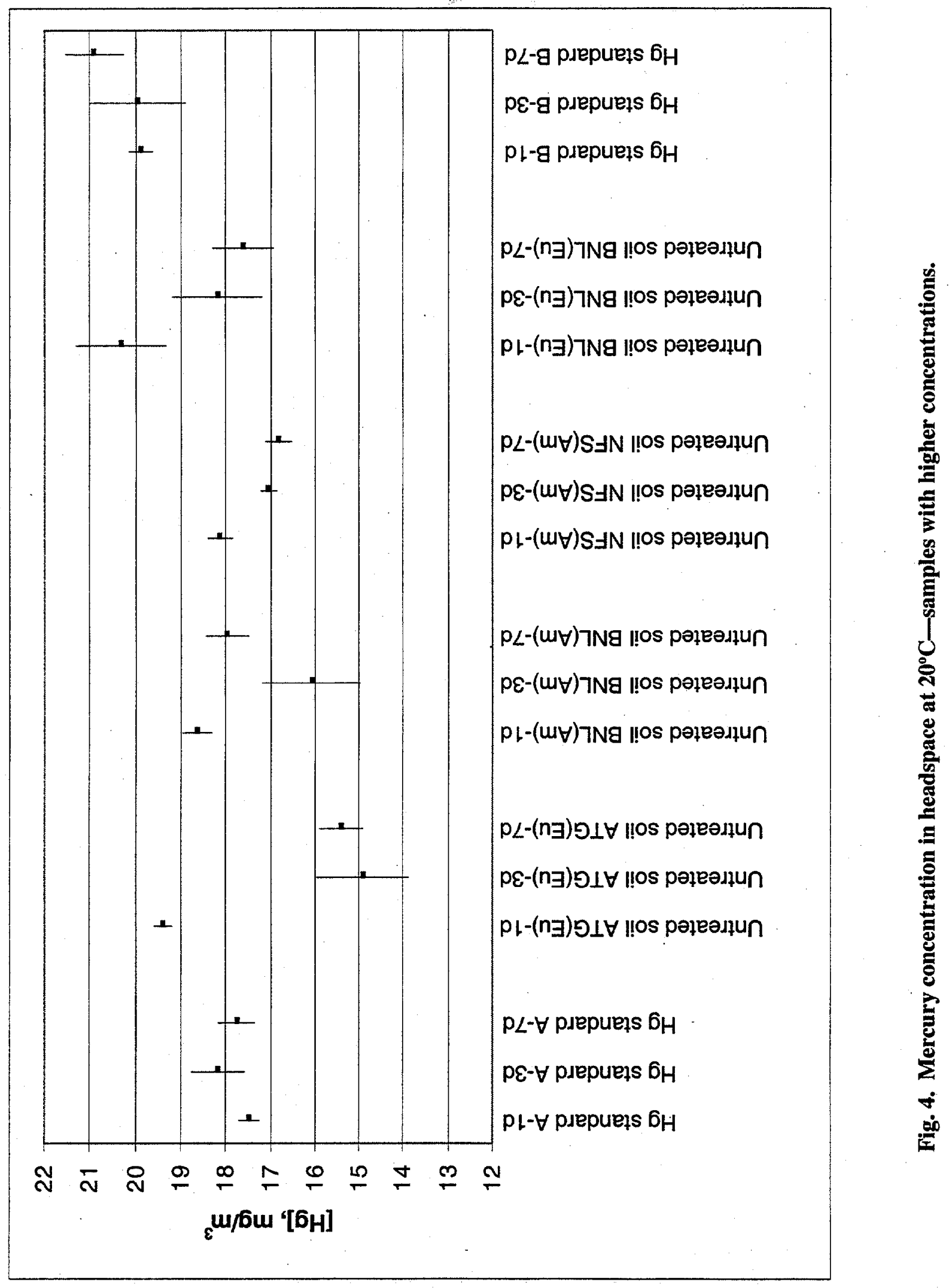




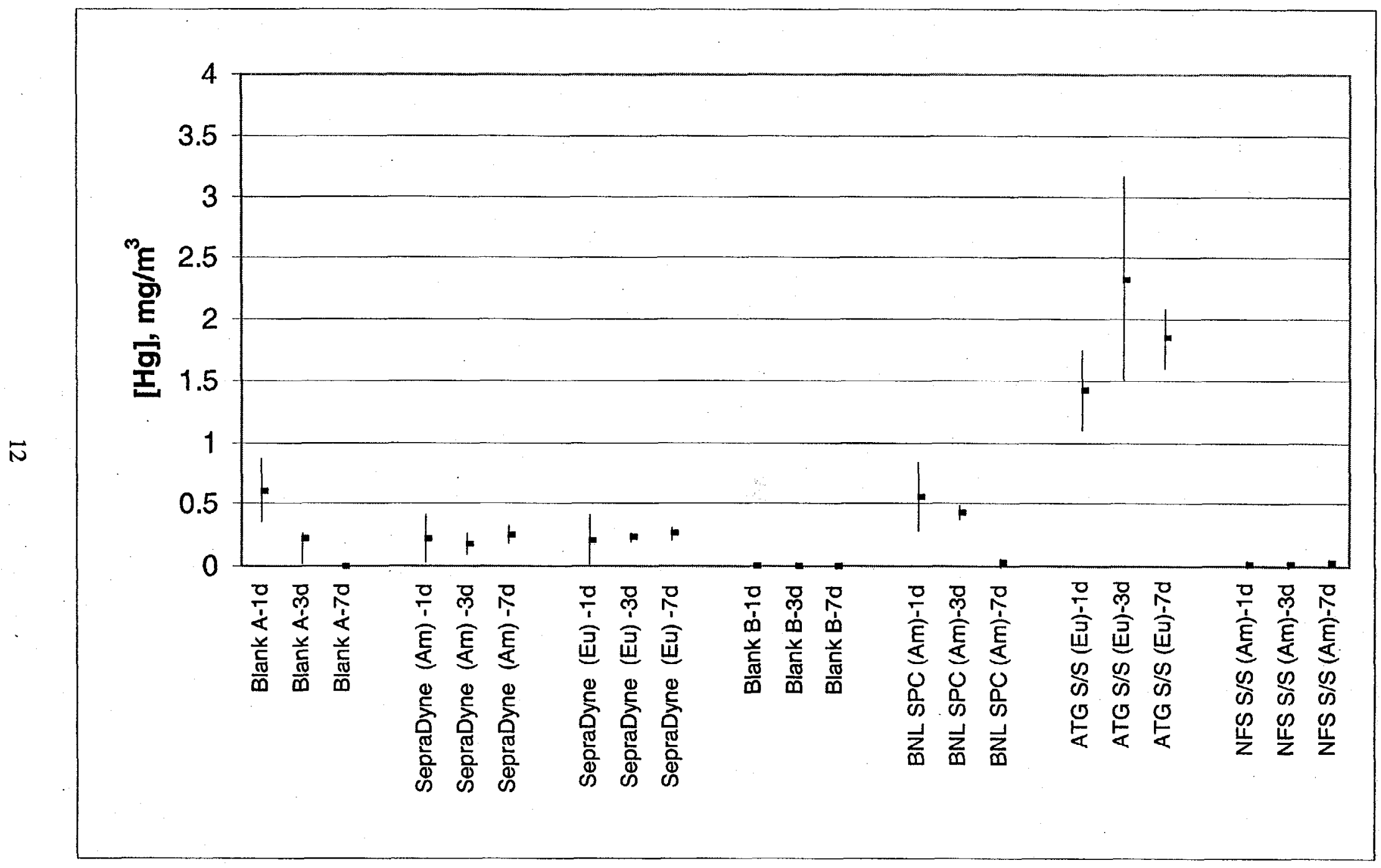

Fig. 5. Mercury concentration in headspace at $60^{\circ} \mathrm{C}$ - samples with lower concentrations. 


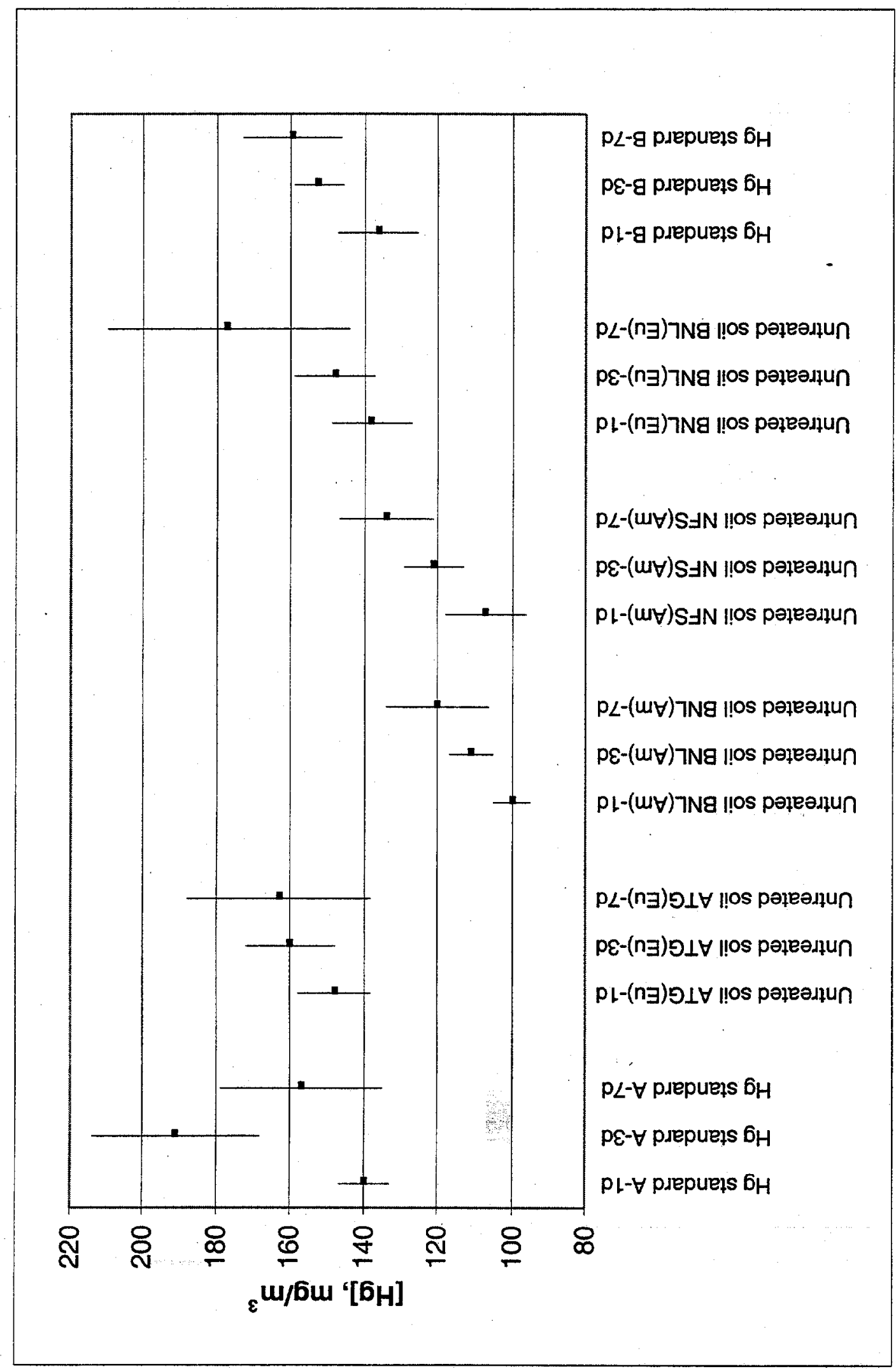


Table 5. Instrument sensitivity as a function

of the volume analyzed

\begin{tabular}{cc}
\hline Sample size $(\mathrm{mL})$ & Sensitivity $\left(\mathrm{mg} / \mathrm{m}^{3}\right)$ \\
\hline 0.2 & 1.31 \\
0.3 & 0.875 \\
1 & 0.2625 \\
2 & 0.1313 \\
3 & 0.0875 \\
10 & 0.0263 \\
\hline
\end{tabular}

\subsection{QA/QC Pure Mercury Samples}

The concentration of mercury in the headspace of the mercury standard was found to be $\sim 1-3 \mathrm{mg} / \mathrm{m}^{3}$ at the lowest temperature, compared with the theoretical values of $2.42,2.67$, and 2.94 at 1,2 , and $3^{\circ} \mathrm{C}$, respectively. At ambient temperature, which was $\sim 21-22^{\circ} \mathrm{C}$, the measurements were found to be in the 17 to $21-\mathrm{mg} / \mathrm{m}^{3}$ range, compared with the theoretical values of 15.54 and 19.91 at 22 and $25^{\circ} \mathrm{C}$, respectively. Larger deviations from the theoretical values were found for the samples maintained at $60^{\circ} \mathrm{C}$, which were determined to be lower. These deviations were probably due to the smaller volume of headspace gas analyzed; only $0.2 \mathrm{~mL}$ was used so that the sensor would not become saturated too rapidly. It was also noticed that the temperature of the bath dropped when the cover was removed during the measurements.

\subsection{QA/QC Blank Samples}

The samples tested in May on days 1 and 3 appear to have high mercury concentrations, while the results at day 7 are closer to zero. A problem with the instrument is a possible explanation for the high concentration value; however, both the sensitivity of the instrument and the volume of sample actually analyzed account for the insignificant difference in value. As shown in Table 5 , the sensitivity of the instrument for $1 \mathrm{~mL}$ is $0.26 \mathrm{mg} / \mathrm{m}^{3}$. This volume was used for the measurement of the blank on day 1 at a temperature of $2^{\circ} \mathrm{C}$. On day 3 , a volume of $3 \mathrm{~mL}$ was analyzed and the sensitivity for that volume was $\sim 0.09 \mathrm{mg} / \mathrm{m}^{3}$. Finally on day 7 , a volume of $10 \mathrm{~mL}$ was sampled, which corresponded to a sensitivity of $0.026 \mathrm{mg} / \mathrm{m}^{3}$. The same volume of $10 \mathrm{~mL}$ was used for the blank at $20^{\circ} \mathrm{C}$. For the September blank sample, a volume of $10 \mathrm{~mL}$ was used at 2 and $20^{\circ} \mathrm{C}$. 


\subsection{Untreated Soil}

The untreated soil was a sand-like matrix with $\sim 10 \%$ moisture. The larger pebbles had been removed through use of a 2-mm sieve. The data obtained for the untreated soils showed that the soils released as much mercury vapor in the headspace as pure mercury, even though the total concentration of mercury in the soil was only $\sim 4500 \mathrm{mg} / \mathrm{kg}$. As expected, the release of mercury vapor was independent of the predominant radionuclide contaminating the soil. Some very small droplets of elemental mercury were found in the soil, confirming the data obtained. Another interesting observation is that the $10 \%$ moisture content did not modify the concentration of mercury in the headspace. These observations should emphasize the importance of immobilizing the mercury-even when present at low concentrations -into a form that is stable and able to retain all the mercury present in the waste. For waste samples contaminated with elemental mercury, as in this demonstration, the measurement of mercury vapor in the headspace of the waste form could also serve as a way to ensure that complete conversion of elemental mercury was achieved through the process.

Two years ago, the Mercury Working Group conducted a demonstration in which commercial vendors tested their processes for amalgamating elemental mercury (1). One vendor used amalgamation with metals, but the process did not yield $100 \%$ conversion and some small droplets of mercury were visible in association with the amalgam formed. These samples showed as much mercury vapor in the headspace as that found for pure mercury. Such data corroborate the hypothesis that this type of measurement could serve as an indicator of the completion of the amalgamation process when stabilizing elemental mercury.

These findings corroborate the results obtained by Gorin et al. ( 7$)$ and others $(3,6)$. In this experiment, very rapid kinetics of equilibrium existed between the sample and the headspace, and equilibrium was reached within 1 day. A study performed at Vanderbilt University (3) provides an explanation concerning the mechanisms of mercury stabilization, depending on which chemical forms of mercury exist in the waste.

\subsection{Thermal Desorption - SepraDyne Process}

The soil treated by thermal desorption was a sandy, dusty, black material that had been sifted through a 2-mm sieve. This process was the baseline for the treated samples since it is the current EPA-approved treatment process for waste contaminated with levels of mercury above $260 \mathrm{ppm}$. The concentration of mercury vapor in the headspace was found to be the same as the blank and involved the same sensitivity issue since the volumes used were the same as those analyzed in May. The difference with the blank is that a volume of $2 \mathrm{~mL}$ was analyzed on day 1 at $2^{\circ} \mathrm{C}$ with a corresponding sensitivity of $\sim 0.13 \mathrm{mg} / \mathrm{m}^{3}$.

\subsection{Solidification/Stabilization Using Sulfur Polymer Cement - BNL Process}

The soil treated by sulfur polymer cement was cast in a monolith form the size of a 1-gal can. The material was broken into pieces small enough to use a jaw crusher to fit the 2-mm sieve. As found in the results for FY 1999, mercury-contaminated wastes treated with sulfide yielded the most stable waste forms. The waste treated with sulfur polymer cement showed very little or no release of mercury vapor, even at higher temperatures. Its effectiveness is comparable to that of the thermal desorption process. 


\subsection{Solidification/Stabilization Using Portland Cement-Based Additives - ATG Process}

The soil treated with this process was received in the form of a gray, crushed material with hard clumps, much like cement-based materials. The moisture content of the sample was less than $5 \%$. Larger particles had to be size reduced in a mortar to fit the 2-mm sieve. Even though the total amount of mercury was not elevated, this process appeared to release the most mercury of the samples tested. At $20^{\circ} \mathrm{C}$, the release measured slightly above the TLV of $0.05 \mathrm{mg} / \mathrm{m}^{3}$. This could indicate that the elemental mercury was not completely amalgamated prior to the solidification of the cement matrix.

\subsection{Solidification/Stabilization Using Proprietary Additives - NFS Process}

The sample received from this process was a sand-like material that was darker than the original soil. Unlike the sulfur polymer cement and the ATG processes, this process generated a flowing, rather than a hard, final material. The moisture content-15\%-was slightly higher than that in the original soil. This process appeared to be successful in binding the elemental mercury in a form in which mercury vapors cannot be generated since at higher temperatures, the release is not significant and is comparable to that achieved via thermal desorption processes.

\section{CONCLUSIONS}

Two contaminated waste soils, each with a mercury level of about $4500 \mathrm{ppm}$, were used for testing different processes that claimed to reduce the mercury to levels below the regulatory limit: that is, 0.025 $\mathrm{mg} / \mathrm{L}$ in the TCLP leachate of the sample as stated in EPA method SW846-1311. One vendor measured the mercury-reacting ionic species that could combine with mercury, and the total did not account for all the mercury present in the waste. During the testing, some tiny droplets of elemental mercury could be seen in the untreated soil.

The four processes evaluated - thermal desorption by SepraDyne, solidification/stabilization using sulfur polymer cement by BNL, solidification/stabilization using portland cement additives by ATG, and solidification/stabilization using proprietary additives by NFS - as reported by the vendor to the Mercury Working Group, reached the goal of achieving TCLP results below the regulatory limit $(0.025 \mathrm{mg} / \mathrm{L})$. In this study, when the samples were subjected to a modified TCLP test, the concentrations of mercury in the TCLP leachates were found to be slightly above $0.025 \mathrm{mg} / \mathrm{L}$ in some cases.

The EPA was also interested in comparing the TCLP results with some measurements of the mercury vapor concentration in the headspace of the waste form. Measurements of the mercury vapor in the headspace of the untreated soils showed that the soils attained about the same equilibrium vapor pressure of mercury as the elemental mercury standard used in the experiment. The samples treated by either process (thermal desorption or solidification/stabilization) showed greatly reduced vapor concentrations (up to a' factor of about 350 ). The soil treated by ATG appeared to exhibit the highest mercury vapor pressure at ambient temperature, while the other processes gave results comparable to those obtained by thermal desorption. 
Because of the larger experimental uncertainty related to the instrument sensitivity for the lowerconcentration results, a direct comparison of the results with the TLV is not appropriate. If comparison with the TLV was required, the test would have to be performed under strict conditions where parameters such as temperature, humidity, physical state of the waste form, and elapsed time between the treatment and testing are controlled and kept constant for all processes tested.

\section{REFERENCES}

1. C. H. Mattus, Measurements of Mercury Released from Amalgams and Sulfide Compounds, ORNL/TM-13728, Oak Ridge National Laboratory, April 1999.

2. W. P. Hamilton and A. R. Bowers, "Determination of Acute Hg Emissions from Solidified/Stabilized Cement Waste Forms," Waste Management 17(1), 25-32 (1997).

3. S. E. Lindberg et al., Pathways of Mercury in Solid Waste Disposal, ORNL Sampling Operations Summary and Preliminary Data Report for PaMSWaD-I, Brevard County Landfill, Oak Ridge National Laboratory and Florida Department of Environmental Protection, February 6, 1999.

4. Mercury Amalgamation, Mixed Waste Focus Area, Technology Development Requirements Document, INEL/EXT-97-00314, Rev. 0, March 1997.

5. D. M. Considine and G. D. Considine, eds., Encyclopedia of Chemistry, 4th ed., Van Nostrand Reinhold, New York, 1984.

6. A. A. Kriger and R. R. Turner, Field Analysis of Mercury in Water, Sediment and Soil Using Static Headspace Analysis, CONF-940729-2, 1994.

7. A. H. Gorin, J. H. Leckey, and L. E. Nulf, Final Disposal Options for Mercury/Uranium Mixed Wastes from the Oak Ridge Reservation, Y-DZ-1106, Oak Ridge Y-12 Plant, August 1994. 
APPENDIX 


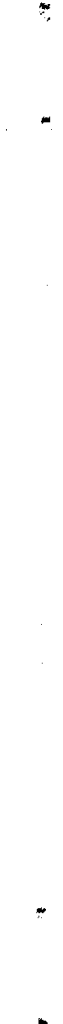


Table A.1. Summary of data for the samples maintained at $2^{\circ} \mathrm{C}$

\begin{tabular}{|c|c|c|c|c|c|c|c|c|c|c|c|c|c|c|c|c|}
\hline \multirow{2}{*}{$\begin{array}{l}\text { Sample } \\
\text { name } \\
\text { Blank -A (1) }\end{array}$} & \multicolumn{2}{|l|}{$\begin{array}{l}\text { Size } \\
(\mathrm{mL})\end{array}$} & \multicolumn{2}{|c|}{$\begin{array}{l}1 \text { day - } 05 / 09 / 00 \\
\text { readings }\end{array}$} & \multicolumn{3}{|c|}{$\begin{array}{c}{[\mathrm{Hg}]} \\
\left(\mathrm{mg} / \mathrm{m}^{3}\right)\end{array}$} & \multicolumn{3}{|c|}{$\begin{array}{c}3 \text { days - 05/11/00 } \\
\text { readings }\end{array}$} & \multicolumn{2}{|l|}{$\begin{array}{c}{[\mathrm{Hg}]} \\
\left(\mathrm{mg} / \mathrm{m}^{3}\right)\end{array}$} & \multicolumn{2}{|c|}{$\begin{array}{c}7 \text { days - } 05 / 15 / 00 \\
\text { readings }\end{array}$} & \multicolumn{2}{|r|}{$\begin{array}{c}{[\mathrm{Hg}]} \\
\left(\mathrm{mg} / \mathrm{m}^{3}\right)\end{array}$} \\
\hline & $1 \mathrm{~d}: 1$ & 0.008 & 0.004 & 0 & 0.003 & 0.328 & 0.004 & 0 & 0 & 0.004 & 0.058 & 0 & 0 & 0 & 0 & 0.000 \\
\hline Blank- A (2) & $3 \mathrm{~d}: 3$ & 0.004 & 0.004 & 0 & 0.004 & 0.263 & 0.004 & 0.003 & 0 & 0 & 0.051 & 0 & 0 & 0 & 0 & 0.000 \\
\hline Blank-A (3) & $7 \mathrm{~d}: 10$ & 0.006 & 0 & 0.003 & 0 & 0.197 & 0.004 & 0.004 & 0.004 & 0 & 0.088 & 0 & 0 & 0.004 & 0 & 0.009 \\
\hline Average & & & & & & 0.263 & & & & & 0.066 & & & & & 0.003 \\
\hline Sx & & & & & & 0.217 & & & & & 0.056 & & & & & 0.010 \\
\hline Error & & & & & & 0.14 & & & & & 0.04 & & & & & 0.01 \\
\hline Mercury standard A (1) & $1 \mathrm{~d}: 2$ & 0.046 & 0.041 & 0.048 & 0.03 & 1.805 & 0.038 & 0.042 & 0.049 & 0.046 & 1.914 & 0.079 & 0.08 & 0.077 & 0.076 & 2.275 \\
\hline Mercury standard A (2) & $3 \mathrm{~d}: 2$ & 0.035 & 0.036 & 0.035 & 0.035 & 1.542 & 0.047 & 0.043 & 0.044 & 0.048 & 1.991 & 0.077 & 0.075 & 0.077 & 0.078 & 2.239 \\
\hline Mercury standard A (3) & $7 \mathrm{~d}: 3$ & 0.04 & 0.041 & 0.04 & 0.04 & $1.761^{\circ}$ & 0.044 & 0.041 & 0.046 & 0.042 & 1.892 & 0.085 & 0.081 & 0.081 & 0.081 & 2.392 \\
\hline Average & & & & & & 1.703 & & & & & 1.932 & & & & & 2.302 \\
\hline Sx & & & & & & 0.211 & & & & & 0.133 & & & & & 0.078 \\
\hline Error & & & & & & 0.13 & & & & & 0.08 & & & & & 0.05 \\
\hline Untreated soil ATG(Eu)-(1) & $1 \mathrm{~d}: 2$ & 0.063 & 0.064 & 0.063 & 0.059 & 2.723 & 0.051 & 0.05 & 0.048 & 0.051 & 2.188 & 0.099 & 0.1 & 0.097 & 0.096 & 2.858 \\
\hline Untreated soil ATG(Eu)-(2) & $3 \mathrm{~d}: 2$ & 0.059 & 0.058 & 0.061 & 0.059 & 2.592 & 0.037 & 0.026 . & 0.029 & 0.033 & 1.367 & 0.1 & 0.103 & 0.103 & 0.1 & 2.960 \\
\hline Untreated soil ATG(Eu)-(3) & $7 \mathrm{~d}: 3$ & 0.062 & 0.057 & 0.059 & 0.048 & 2.472 & 0.09 & 0.083 & 0.082 & 0.084 & 3.708 & 0.114 & 0.1 & 0.114 & 0.11 & 3.194 \\
\hline Average & & & & & & 2.596 & & & & & 2.421 & & & & & 3.004 \\
\hline Sx & & & & & & 0.176 & & & & & 0.979 & & & & & 0.174 \\
\hline Error & & & & & & 0.11 & & & & & 0.62 & & & & & 0.11 \\
\hline Untreated soil BNL(Am)-(1) & $1 \mathrm{~d}: 2$ & 0.065 & 0.062 & 0.055 & 0.063 & 2.680 & 0.034 & 0.039 & 0.039 & 0.038 & 1.641 & 0.087 & 0.085 & 0.084 & 0.085 & 2.486 \\
\hline Untreated soil BNL(Am)-(2) & $3 \mathrm{~d}: 2$ & 0.052 & 0.056 & 0.061 & 0.057 & 2.472 & 0.042 & 0.04 & 0.039 & 0.035 & 1.706 & 0.098 & 0.1 & 0.097 & 0.096 & 2.851 \\
\hline Untreated soil BNL(Am)-(3) & $7 \mathrm{~d}: 3$ & 0.066 & 0.062 & 0.062 & 0.065 & 2.789 & 0.046 & 0.04 & 0.039 & 0.042 & 1.827 & 0.073 & 0.071 & 0.053 & 0.059 & 1.867 \\
\hline Average & & & & & & 2.647 & & & & & 1.724 & & & & & 2.401 \\
\hline Sx & & & & & & 0.187 & & & & & 0.132 & & & & & 0.431 \\
\hline Error & & & & & & 0.12 & & & & & 0.08 & & & & & 0.27 \\
\hline
\end{tabular}


Table A.1 (cont.)

\begin{tabular}{|c|c|c|c|c|c|c|c|c|c|c|c|c|c|c|c|c|}
\hline \multirow{2}{*}{$\begin{array}{l}\text { Sample } \\
\text { name } \\
\text { Untreated soil NFS(Am)-(1) }\end{array}$} & \multirow{2}{*}{$\begin{array}{l}\text { Size } \\
(\mathrm{mL})\end{array}$} & \multirow[b]{2}{*}{0.078} & \multicolumn{2}{|c|}{$\begin{array}{c}1 \text { day }-05 / 09 / 00 \\
\text { readings }\end{array}$} & \multirow[b]{2}{*}{0.077} & \multirow{2}{*}{$\begin{array}{c}\begin{array}{c}{[\mathrm{Hg}]} \\
\left(\mathrm{mg} / \mathrm{m}^{3}\right)\end{array} \\
3.347\end{array}$} & \multirow[b]{2}{*}{0.05} & \multicolumn{2}{|c|}{$\begin{array}{c}3 \text { days - } 05 / 11 / 00 \\
\text { readings }\end{array}$} & \multirow{2}{*}{0.053} & \multirow{2}{*}{$\frac{\begin{array}{c}{[\mathrm{Hg}]} \\
\left(\mathrm{mg} / \mathrm{m}^{3}\right)\end{array}}{2.275}$} & \multirow[b]{2}{*}{0.092} & \multicolumn{3}{|c|}{$\begin{array}{c}7 \text { days - } 05 / 15 / 00 \\
\text { readings } \\
\end{array}$} & \multirow{2}{*}{$\begin{array}{c}\begin{array}{c}{[\mathrm{Hg}]} \\
\left(\mathrm{mg} / \mathrm{m}^{3}\right)\end{array} \\
2.683\end{array}$} \\
\hline & & & 0.077 & 0.074 & & & & 0.051 & 0.054 & & & & 0.096 & 0.09 & 0.09 & \\
\hline Untrealed soil NFS(Am)-(2) & $3 \mathrm{~d}: 2$ & 0.06 & 0.056 & 0.055 & 0.056 & 2.483 & 0.055 & 0.049 & 0.052 & 0.047 & 2.220 & 0.096 & 0.085 & 0.086 & 0.08 & 2.530 \\
\hline Untreated soil NFS(Am)-(3) & $7 \mathrm{~d}: 3$ & 0.055 & 0.053 & 0.049 & 0.052 & 2.286 & 0.038 & 0.035 & 0.023 & 0.023 & 1.302 & 0.071 & 0.067 & 0.064 & 0.057 & 1.889 \\
\hline Average & & & & & & 2.705 & & & & & 1.932 & & & & & 2.367 \\
\hline Sx & & & & & & 0.468 & & & & & 0.486 & & & & & 0.370 \\
\hline Error & & & & & & $\mathbf{0 . 3 0}$ & & & & & $\mathbf{0 . 3 1}$ & & & & & 0.24 \\
\hline Untreated soil BNL(Eu)-(1) & $1 \mathrm{~d}: 2$ & 0.051 & 0.055 & 0.053 & 0.053 & 2.319 & 0.043 & 0.079 & 0.08 & 0.081 & 3.095 & 0.087 & 0.083 & 0.066 & 0.063 & 2.180 \\
\hline Untreated soil BNL(Eu)-(2) & $3 \mathrm{~d}: 2$ & 0.055 & 0.05 & 0.043 & 0.052 & 2.188 & 0.094 & 0.052 & 0.041 & & 2.727 & 0.08 & 0.053 & 0.065 & 0.052 & 1.823 \\
\hline Untreated soil BNL(Eu)-(3) & $7 \mathrm{~d}: 3$ & 0.059 & 0.051 & 0.052 & 0.05 & 2.319 & 0.08 & 0.077 & 0.07 & 0.075 & 3.303 & 0.109 & 0.078 & 0.068 & 0.07 & 2.370 \\
\hline Average & & & & & & 2.275 & & & & & 3.042 & & & & & 2.124 \\
\hline $\mathrm{Sx}$ & & & & & & 0.160 & & & & & 0.716 & & & & & 0.442 \\
\hline Error & & & & & & 0.10 & & & & & 0.45 & & & & & 0.28 \\
\hline SepraDyne $(\Lambda m)-(1)$ & $1 \mathrm{~d}: 2$ & 0.008 & 0.004 & 0.004 & 0.004 & 0.219 & 0.005 & 0 & 0 & 0 & 0.036 & 0.003 & 0.004 & 0 & 0 & 0.015 \\
\hline SepraDyne (Am) - (2) & $3 \mathrm{~d}: 3$ & 0.004 & 0.004 & 0.004 & 0.004 & 0.175 & 0.003 & 0.004 & 0.004 & 0 & 0.080 & 0 & 0 & 0 & $\mathbf{0}$ & 0.000 \\
\hline SepraDyne (Am) - (3) & $7 \mathrm{~d}: 10$ & 0.004 & 0.003 & 0 & & 0.102 & 0.004 & 0.004 & 0.003 & 0 & 0.080 & 0 & 0 & 0 & $\mathbf{0}$ & 0.000 \\
\hline Average & & & & & & 0.165 & & & & . & 0.066 & & & & & 0.005 \\
\hline Sx & & & & & & 0.076 & & & & & 0.057 & & & & & 0.012 \\
\hline Error & & & & & & 0.05 & & & & & 0.04 & & & & & 0.007 \\
\hline SepraDyne (Eu) - (1) & $1 \mathrm{~d}: 2$ & 0.006 & 0.004 & 0.004 & 0.004 & 0.197 & 0.003 & 0 & 0.003 & 0 & 0.044 & 0 & 0 & 0 & $\mathbf{0}$ & 0.000 \\
\hline SepraDyne (Eu) - (2) & $3 \mathrm{~d}: 3$ & 0.005 & 0.003 & 0 & 0.003 & 0.120 & 0 & 0.003 & 0.003 & 0.005 & 0.080 & 0 & $\mathbf{0}$ & $\mathbf{0}$ & $\mathbf{0}$ & 0.000 \\
\hline SepraDyne (Eu) - (3) & $7 \mathrm{~d}: 10$ & 0.004 & 0 & 0 & 0 & 0.044 & 0.006 & 0 & 0 & 0 & 0.044 & 0 & 0 & 0 & 0 & 0.000 \\
\hline Average & & & & & & 0.120 & & & & & 0.056 & & & & & 0.000 \\
\hline Sx & & & & & & 0.091 & & & & & 0.061 & & & & & 0.000 \\
\hline Error & & & & & & 0.06 & & & & & 0.04 & & & & & 0.000 \\
\hline
\end{tabular}


Table A-1 (cont.)

\begin{tabular}{|c|c|c|c|c|c|c|c|c|c|c|c|c|c|c|c|c|}
\hline $\begin{array}{l}\text { Sample } \\
\text { name } \\
\end{array}$ & $\begin{array}{l}\text { Size } \\
(\mathrm{mL})\end{array}$ & & $\begin{array}{r}1 \text { day - } 0 \\
\text { readi }\end{array}$ & $\begin{array}{l}9 / 26 / 00 \\
\text { ngs }\end{array}$ & & $\begin{array}{c}{[\mathrm{Hg}]} \\
\left(\mathrm{mg} / \mathrm{m}^{3}\right)\end{array}$ & & $\begin{array}{r}3 \text { days - } \\
\text { reac } \\
\end{array}$ & $\begin{array}{l}09 / 28 / 00 \\
\text { ings }\end{array}$ & & $\begin{array}{c}{[\mathrm{Hg}]} \\
\left(\mathrm{mg} / \mathrm{m}^{3}\right)\end{array}$ & & $\begin{array}{r}7 \text { days - } \\
\text { read }\end{array}$ & $\begin{array}{l}10 / 02 / 00 \\
\text { ings }\end{array}$ & & $\begin{array}{c}{[\mathrm{Hg}]} \\
\left(\mathrm{mg} / \mathrm{m}^{3}\right)\end{array}$ \\
\hline Blank -B (1) & $1 \mathrm{~d}: 10$ & 0 & 0 & 0 & & 0.000 & $\mathbf{0}$ & 0 & 0 & & 0.000 & 0 & 0 & 0 & & 0.000 \\
\hline Blank- B (2) & $3 \mathrm{~d}: 10$ & 0 & 0 & 0 & & 0.000 & 0 & 0 & 0 & & 0.000 & 0 & 0 & 0 & & 0.000 \\
\hline Blank-B (3) & $7 \mathrm{~d}: 10$ & 0 & 0 & 0 & & 0.000 & 0 & 0 & 0 & & 0.000 & 0 & 0 & $\mathbf{0}$ & & 0.000 \\
\hline Average & & & & & & 0.000 & & & & & 0.000 & & & & & 0.000 \\
\hline $\mathrm{Sx}$ & & & & & & 0.000 & & & & & 0.000 & & & . & & 0.000 \\
\hline Error & & & & & & 0.00 & & & & & 0.00 & & & & & 0.00 \\
\hline Mercury standard B (1) & $1 \mathrm{~d}: 3$ & 0.13 & 0.113 & 0.111 & 0.108 & 3.369 & 0.094 & 0.09 & 0.091 & 0.104 & 2.764 & 0.105 & 0.1 & 0.095 & 0.095 & 2.880 \\
\hline Mercury standard B (2) & $3 \mathrm{~d}: 3$ & 0.111 & 0.099 & 0.098 & 0.116 & 3.092 & 0.094 & 0.091 & 0.087 & 0.085 & 2.603 & 0.098 & 0.102 & 0.1 & 0.1 & 2.917 \\
\hline Mercury standard B (3) & $7 \mathrm{~d}: 3$ & 0.093 & 0.094 & 0.09 & 0.88 & 8.436 & 0.098 & 0.101 & 0.095 & 0.098 & 2.858 & 0.102 & 0.1 & 0.101 & 0.105 & 2.975 \\
\hline Average & & & & & & 4.966 & & & & & 2.742 & & & & & 2.924 \\
\hline Sx & & & . & & & 6.250 & & & & & 0.157 & & & & & 0.089 \\
\hline Error & & & & & & 3.97 & & & & & 0.099 & & & & & 0.06 \\
\hline BNL SPC (Am)-(1) & $1 \mathrm{~d}: 10$ & 0 & 0 & 0 & 0 & 0.000 & 0 & 0 & 0 & 0 & 0.000 & 0.004 & 0 & 0.003 & 0.004 & 0.024 \\
\hline BNL SPC (Am)-(2) & $3 \mathrm{~d}: 10$ & 0 & 0 & $\mathbf{0}$ & 0 & 0.000 & 0 & 0 & 0.003 & 0.003 & 0.013 & 0.004 & 0 & 0 & 0.003 & 0.015 \\
\hline BNL SPC (Am)-(3) & $7 \mathrm{~d}: 10$ & 0.003 & 0.003 & $\mathbf{0}$ & 0.003 & 0.020 & 0 & 0.003 & 0.004 & 0 & 0.015 & 0 & 0 & 0 & 0 & 0.000 \\
\hline Average & & & & & & 0.007 & & & & & 0.009 & & & & & 0.013 \\
\hline Sx & & & & & & 0.011 & & & & & 0.014 & & & & & 0.016 \\
\hline Error & & & & & & 0.007 & & & & & 0.009 & & & & & 0.01 \\
\hline ATG S/S (Eu)-(1) & $1 \mathrm{~d}: 10$ & 0.009 & 0 & 0 & 0 & 0.020 & 0.013 & 0 & 0 & 0 & 0.028 & 0 & 0 & 0 & 0 & 0.000 \\
\hline ATG S/S (Eu)-(2) & $3 \mathrm{~d}: 10$ & 0.003 & 0.004 & 0.006 & 0.005 & 0.039 & 0 & 0.006 & 0.005 & 0.004 & 0.033 & 0 & 0 & 0 & 0 & 0.000 \\
\hline ATG S/S (Eu)-(3) & $7 \mathrm{~d}: 10$ & 0.007 & 0.007 & 0.007 & 0.008 & 0.063 & 0.008 & 0.007 & 0.006 & 0.005 & 0.057 & 0 & 0 & 0 & 0 & 0.000 \\
\hline Average & & & & & & 0.041 & & & & & 0.039 & & & & & 0.000 \\
\hline $\mathrm{Sx}$ & & & & & & 0.027 & & & & & 0.034 & & & & & 0.000 \\
\hline Error & & & & & & 0.017 & & & & & 0.021 & & & & & 0.00 \\
\hline NFS S/S (Am)-(1) & $1 \mathrm{~d}: 10$ & 0.008 & 0.005 & 0.007 & 0.008 & 0.061 & 0.012 & 0.006 & 0.006 & 0.013 & 0.081 & 0 & 0 & 0 & 0 & 0.000 \\
\hline NFS S/S (Am)-(2) & $3 \mathrm{~d}: 10$ & 0.008 & 0.008 & 0.006 & 0.007 & 0.063 & 0.008 & 0.013 & 0.02 & 0.008 & 0.107 & 0 & 0 & 0 & 0 & 0.000 \\
\hline NFS S/S (Am)-(3) & $7 \mathrm{~d}: 10$ & 0.008 & 0.007 & 0.006 & 0.004 & 0.055 & 0.013 & 0.008 & 0.011 & 0.01 & 0.092 & 0 & 0 & 0 & 0 & 0.000 \\
\hline Average & & & & & & 0.060 & & & & & 0.093 & & & & & 0.000 \\
\hline Sx & & & & & & 0.011 & & & & & 0.033 & & & & & 0.000 \\
\hline Error & & & & & & 0.007 & & & & & 0.021 & & & & & 0.00 \\
\hline
\end{tabular}


Table A-2. Summary of data for the samples maintained at $20^{\circ} \mathrm{C}$

\begin{tabular}{|c|c|c|c|c|c|c|c|c|c|c|c|c|c|c|c|c|}
\hline \multirow{2}{*}{$\begin{array}{l}\text { Sample } \\
\text { name } \\
\text { Blank -A (1) }\end{array}$} & \multirow{2}{*}{$\begin{array}{l}\begin{array}{l}\text { Size } \\
(\mathrm{mL})\end{array} \\
1 \mathrm{~d}: 10\end{array}$} & \multicolumn{4}{|c|}{$\begin{array}{c}1 \text { day }-05 / 09 / 00 \\
\text { readings }\end{array}$} & \multirow{2}{*}{$\begin{array}{c}\begin{array}{c}{[\mathrm{Hg}]} \\
\left(\mathrm{mg} / \mathrm{m}^{3}\right)\end{array} \\
0.000\end{array}$} & \multicolumn{4}{|c|}{$\begin{array}{c}3 \text { days }-05 / 11 / 00 \\
\text { readings }\end{array}$} & \multirow{2}{*}{$\begin{array}{c}\begin{array}{c}{[\mathrm{Hg}]} \\
\left(\mathrm{mg} / \mathrm{m}^{3}\right)\end{array} \\
0.042\end{array}$} & \multicolumn{4}{|c|}{$\begin{array}{c}7 \text { days }-05 / 15 / 00 \\
\text { readings }\end{array}$} & \multirow{2}{*}{$\begin{array}{c}\frac{[\mathrm{Hg}]}{\left(\mathrm{mg} / \mathrm{m}^{3}\right)} \\
0.000\end{array}$} \\
\hline & & 0 & 0 & 0 & & & 0.005 & 0.005 & 0.005 & 0.004 & & 0 & 0 & 0 & 0 & \\
\hline Blank- A (2) & $3 \mathrm{~d}: 10$ & 0 & 0 & 0 & & 0.000 & 0.008 & 0.004 & 0.003 & 0.003 & 0.039 & 0 & 0 & 0 & 0 & 0.000 \\
\hline Blank-A (3) & $7 \mathrm{~d}: 10$ & 0 & 0 & 0 & & 0.000 & 0.006 & 0.004 & 0.004 & 0.005 & 0.042 & 0 & 0 & 0 & 0 & 0.000 \\
\hline Average & & & & & & 0.000 & & & & & 0.041 & & & & & 0.000 \\
\hline $\mathrm{Sx}$ & & & & & & 0.000 & & & & & 0.011 & & & & & 0.000 \\
\hline Error & & & & & & 0.000 & & & & & 0.007 & & & & & 0.000 \\
\hline Mercury standard A (1) & $1 \mathrm{~d}: 1$ & 0.207 & 0.204 & 0.203 & 0.199 & 17.784 & 0.194 & 0.199 & 0.19 & 0.197 & 17.063 & 0.204 & 0.198 & 0.207 & 0.212 & 17.959 \\
\hline Mercury standard A (2) & $3 \mathrm{~d}: 1$ & 0.205 & 0.2 & 0.194 & 0.198 & 17.434 & 0.218 & 0.218 & 0.219 & 0.22 & 19.141 & 0.212 & 0.211 & 0.199 & 0.204 & 18.069 \\
\hline Mercury standard A (3) & $7 \mathrm{~d}: 1$ & 0.199 & 0.197 & 0.2 & 0.192 & 17.238 & 0.219 & 0.208 & 0.204 & 0.206 & 18.309 & 0.199 & 0.208 & 0.191 & 0.189 & 17.216 \\
\hline Average & & & & & & 17.49 & & & & & 18.17 & & & & & 17.75 \\
\hline Sx & & & & & & 0.369 & & & & & 0.920 & & & & & 0.652 \\
\hline Error & & & & & & 0.234 & & & & & 0.584 & & & & & 0.414 \\
\hline Untreated soil ATG(Eu)-(1) & $1 \mathrm{~d}: 1$ & 0.216 & 0.218 & 0.218 & 0.224 & 19.163 & 0.186 & 0.166 & 0.179 & 0.191 & 15.794 & 0.178 & 0.187 & 0.183 & 0.179 & 15.903 \\
\hline Untreated soil ATG(Eu)-(2) & $3 \mathrm{~d}: 1$ & 0.223 & 0.221 & 0.227 & 0.227 & 19.644 & 0.188 & 0.176 & 0.18 & 0.183 & 15.903 & 0.188 & 0.177 & 0.173 & 0.177 & 15.641 \\
\hline Untreated soil ATG(Eu)-(3) & $7 \mathrm{~d}: 1$ & 0.223 & 0.221 & 0.219 & 0.223 & 19.381 & 0.134 & 0.176 & 0.148 & 0.139 & 13.059 & 0.182 & 0.163 & 0.168 & 0.158 & 14.678 \\
\hline Average & & & & & & 19.40 & & & & & 14.92 & & & & & 15.41 \\
\hline $\mathrm{Sx}$ & & & & & & 0.293 & & & & & 1.636 & & & & & 0.771 \\
\hline Error & & & & & & 0.186 & & & & & 1.039 & & & & & 0.489 \\
\hline Untreated soil BNL(Am)-(1) & $1 \mathrm{~d}: 1$ & 0.215 & 0.224 & 0.22 & 0.212 & 19.053 & 0.185 & 0.186 & 0.188 & 0.18 & 16.166 & 0.225 & 0.22 & 0.21 & 0.202 & 18.747 \\
\hline Untreated soil BNL(Am)-(2) & $3 \mathrm{~d}: 1$ & 0.215 & 0.215 & 0.213 & 0.212 & 18.703 & 0.208 & 0.198 & 0.222 & 0.198 & 18.069 & 0.208 & 0.204 & 0.201 & 0.199 & 17.763 \\
\hline Untreated soil BNL(Am)-(3) & $7 \mathrm{~d}: 1$ & 0.202 & 0.217 & 0.208 & 0.203 & 18.156 & 0.162 & 0.159 & 0.16 & 0.158 & 13.978 & 0.203 & 0.199 & 0.198 & 0.194 & 17.369 \\
\hline Average & & & & & & 18.64 & & & & & 16.07 & & & & & 17.96 \\
\hline Sx & & & & & & 0.533 & & & & & 1.752 & & & & & 0.770 \\
\hline Error & & & & & & 0.339 & & & & & 1.112 & & & & & 0.489 \\
\hline
\end{tabular}


Table A-2 (cont.)

\begin{tabular}{|c|c|c|c|c|c|c|c|c|c|c|c|c|c|c|c|c|}
\hline $\begin{array}{l}\text { Sample } \\
\text { name }\end{array}$ & $\begin{array}{l}\text { Size } \\
(\mathrm{mL})\end{array}$ & & $\begin{array}{r}\text { day - } 0 \\
\text { readi }\end{array}$ & $\begin{array}{l}5 / 09 / 00 \\
\text { ngs }\end{array}$ & & $\begin{array}{c}{[\mathrm{Hg}]} \\
\left(\mathrm{mg} / \mathrm{m}^{3}\right)\end{array}$ & & $\begin{array}{r}3 \text { days - } \\
\text { read }\end{array}$ & $\begin{array}{l}\text { j5/11/00 } \\
\text { ings }\end{array}$ & & $\begin{array}{l}{[\mathrm{Hg}]} \\
\left.\mathrm{mg} / \mathrm{m}^{3}\right)\end{array}$ & & $\begin{array}{c}\text { days - } \\
\text { read } \\
\end{array}$ & $\begin{array}{l}05 / 15 / 0 \\
\text { ings }\end{array}$ & & $\begin{array}{c}{[\mathrm{Hg}]} \\
\left(\mathrm{mg} / \mathrm{m}^{3}\right)\end{array}$ \\
\hline Untreated soil NFS(Am)-(1) & $1 \mathrm{~d}: 1$ & 0.22 & 0.209 & 0.209 & 0.206 & 18.463 & 0.196 & 0.197 & 0.19 & 0.19 & 16.909 & 0.19 & 0.198 & 0.191 & 0.191 & 16.844 \\
\hline Untreated soil NFS(Am)-(2) & $3 \mathrm{~d}: 1$ & 0.21 & 0.202 & 0.212 & 0.205 & 18.134 & 0.194 & 0.197 & 0.193 & 0.195 & 17.041 & 0.199 & 0.199 & 0.192 & 0.199 & 17.259 \\
\hline Untreated soil NFS(Am)-(3) & $7 \mathrm{~d}: 1$ & 0.202 & 0.204 & 0.202 & 0.205 & 17.784 & 0.2 & 0.199 & 0.196 & 0.189 & 17.150 & 0.187 & 0.182 & 0.188 & 0.189 & 16.319 \\
\hline Average & & & & & & 18.13 & & & & & 17.03 & & & & & 16.81 \\
\hline $\mathbf{S x}$ & & & & & & 0.440 & & & & & 0.300 & & & & & 0.465 \\
\hline Error & & & & & & 0.280 & & & & & 0.190 & & & & & 0.295 \\
\hline Untreated soil BNL(Eu)-(1) & $1 \mathrm{~d}: 1$ & 0.208 & 0.212 & 0.21 & 0.208 & 18.331 & 0.222 & 0.219 & 0.229 & 0.213 & 19.316 & 0.222 & 0.188 & 0.203 & 0.203 & 17.850 \\
\hline Untreated soil BNL(Eu)-(2) & $3 \mathrm{~d}: 1$ & 0.223 & 0.25 & 0.252 & 0.245 & 21.219 & 0.218 & 0.218 & 0.217 & 0.208 & 18.834 & 0.199 & 0.208 & 0.204 & 0.209 & 17.938 \\
\hline Untreated soil BNL(Eu)-(3) & $7 \mathrm{~d}: 1$ & 0.237 & 0.247 & 0.252 & 0.244 & 21.438 & 0.216 & 0.174 & 0.175 & 0.184 & 16.384 & 0.218 & 0.2 & 0.182 & 0.18 & 17.063 \\
\hline Average & & & & & & 20.33 & & & & & 18.18 & & & & & 17.62 \\
\hline Sx & & & & & & 1.558 & & & & & 1.587 & & & & & 1.082 \\
\hline Error & & & & & & 0.989 & & & & & 1.008 & & & & & 0.687 \\
\hline SepraDyne (Am) - (1) & $1 \mathrm{~d}: 10$ & 0 & 0 & 0 & 0 & 0.000 & 0.009 & 0.006 & 0.007 & 0.005 & 0.059 & 0 & 0 & 0 & 0 & 0.000 \\
\hline SepraDyne (Am) - (2) & $3 \mathrm{~d}: 10$ & 0 & 0 & 0 & 0 & 0.000 & 0.008 & 0.006 & 0.006 & 0.006 & 0.057 & 0 & 0 & 0 & 0 & 0.000 \\
\hline SepraDyne (Am) - (3) & $7 \mathrm{~d}: 10$ & 0 & 0 & 0 & 0 & 0.000 & 0.009 & 0.006 & 0.004 & 0.003 & 0.048 & 0 & 0 & 0 & 0 & 0.000 \\
\hline Average & & & & & & 0.000 & & & & & 0.055 & & & & & 0.000 \\
\hline Sx & & & & & & 0.000 & & & & & 0.015 & & & & & 0.000 \\
\hline Error & & & & & & 0.000 & & & & & 0.010 & & & & & 0.000 \\
\hline SepraDyne $(E u)-(1)$ & $1 \mathrm{~d}: 10$ & 0 & 0 & 0 & 0 & 0.000 & 0.006 & 0.004 & 0.004 & 0.004 & 0.039 & 0 & 0 & 0 & 0 & 0.000 \\
\hline SepraDyne (Eu) - (2) & $3 \mathrm{~d}: 10$ & 0 & 0 & 0 & 0 & 0.000 & 0.008 & 0.005 & 0.004 & 0.005 & 0.048 & 0 & 0 & 0 & 0 & 0.000 \\
\hline SepraDyne (Eu) - (3) & $7 \mathrm{~d}: 10$ & 0 & 0 & 0 & 0 & 0.000 & 0.006 & 0.004 & 0.004 & 0.004 & 0.039 & 0 & 0 & 0 & 0 & 0.000 \\
\hline Average & & & & & & 0.000 & & & & & 0.042 & & ( & & & 0.000 \\
\hline $\mathbf{S x}$ & & & & & & 0.000 & & & & & 0.011 & & & & & 0.000 \\
\hline Error & & & & & & 0.000 & & & & & 0.007 & & & & & 0.000 \\
\hline
\end{tabular}


Table A-2 (cont.)

\begin{tabular}{|c|c|c|c|c|c|c|c|c|c|c|c|c|c|c|c|c|}
\hline \multirow{2}{*}{$\begin{array}{l}\text { Sample } \\
\text { name } \\
\text { Blank -B (1) }\end{array}$} & \multirow{2}{*}{$\begin{array}{l}\begin{array}{l}\text { Size } \\
(\mathrm{mL})\end{array} \\
1 \mathrm{~d}: 10\end{array}$} & \multirow[b]{2}{*}{0} & \multicolumn{3}{|c|}{$\begin{array}{l}1 \text { day }-09 / 26 / 00 \\
\text { readings : }\end{array}$} & \multirow{2}{*}{$\begin{array}{c}\begin{array}{c}{[\mathrm{Hg}]} \\
\left(\mathrm{mg} / \mathrm{m}^{3}\right)\end{array} \\
0.000\end{array}$} & \multirow[b]{2}{*}{0} & \multicolumn{3}{|c|}{$\begin{array}{c}3 \text { days - } 09 / 28 / 00 \\
\text { readings }\end{array}$} & \multirow{2}{*}{$\begin{array}{c}\begin{array}{c}{[\mathrm{Hg}]} \\
\left(\mathrm{mg} / \mathrm{m}^{3}\right)\end{array} \\
0.000\end{array}$} & \multicolumn{4}{|c|}{$\begin{array}{l}7 \text { days - } 10 / 02 / 00 \\
\text { readings }\end{array}$} & \multirow{2}{*}{$\begin{array}{c}\begin{array}{c}{[\mathrm{Hg}]} \\
\left(\mathrm{mg} / \mathrm{m}^{3}\right)\end{array} \\
0.000\end{array}$} \\
\hline & & & 0 & 0 & & & & 0 & 0 & & & 0 & 0 & 0 & & \\
\hline Blank- B (2) & $3 \mathrm{~d}: 10$ & 0 & 0 & 0 & & 0.000 & $\mathbf{0}$ & 0 & 0 & & 0.000 & 0 & 0 & 0 & & 0.000 \\
\hline Blank-B (3) & $7 \mathrm{~d}: 10$ & 0 & 0 & 0 & & 0.000 & 0 & 0 & 0 & & 0.000 & 0 & 0 & 0 & & 0.000 \\
\hline Average & & & & & & 0.000 & & & & & 0.000 & & & & & 0.000 \\
\hline $\mathrm{Sx}$ & & & & & & 0.000 & & & & & 0.000 & & & & & 0.000 \\
\hline Error & & & & & & 0.00 & & & & & 0.00 & & & & & 0.00 \\
\hline Mercury standard B (1) & $1 \mathrm{~d}: 1$ & 0.234 & 0.225 & 0.231 & 0.235 & 20.234 & 0.222 & 0.188 & 0.228 & 0.222 & 18.813 & 0.248 & 0.257 & 0.252 & 0.237 & 21.744 \\
\hline Mercury standard B (2) & $3 d: 1$ & 0.226 & 0.235 & 0.223 & 0.225 & 19.884 & 0.23 & 0.265 & 0.256 & 0.244 & 21.766 & 0.252 & 0.239 & 0.236 & 0.229 & 20.913 \\
\hline Mercury standard B (3) & $7 \mathrm{~d}: 1$ & 0.223 & 0.227 & 0.222 & 0.223 & 19.578 & 0.222 & 0.222 & 0.215 & 0.221 & 19.250 & 0.243 & 0.231 & 0.219 & 0.223 & 20.038 \\
\hline Average & & & & & & 19.90 & & & & & 19.94 & & & & & 20.898 \\
\hline Sx & & & & & & 0.417 & & & & & 1.671 & & & & & 1.008 \\
\hline Enror & & & & & & 0.27 & . & & & & 1.06 & & & & & 0.64 \\
\hline BNL SPC (Am)-(1) & $1 \mathrm{~d}: 10$ & 0.003 & 0.007 & 0.005 & 0.007 & 0.048 & $\mathbf{0}$ & 0 & 0 & 0.003 & 0.007 & 0.003 & 0.004 & 0.003 & 0 & 0.022 \\
\hline BNL SPC (Am)- (2) & $3 \mathrm{~d}: 10$ & $\mathbf{0}$ & 0 & 0.009 & 0.005 & 0.031 & 0 & 0 & 0 & 0 & 0.000 & 0.003 & 0.003 & 0.003 & 0 & 0.020 \\
\hline BNL SPC (Am)- (3) & $7 \mathrm{~d}: 10$ & 0.004 & 0.004 & 0.005 & 0 & 0.028 & 0.003 & 0.003 & 0.004 & 0.004 & 0.031 & 0.004 & 0.004 & 0.004 & 0.003 & 0.033 \\
\hline Average & & & & & & 0.036 & & & & & 0.012 & & & & & 0.025 \\
\hline Sx & & & & & & 0.025 & & & & & 0.015 & & & & & 0.012 \\
\hline Error & & & & & & 0.02 & & & & & 0.01 & & & & & 0.01 \\
\hline ATG S/S (Eu)-(1) & $1 \mathrm{~d}: 10$ & 0 & 0.006 & 0.012 & 0.009 & 0.059 & 0.013 & 0.011 & 0.009 & 0.009 & 0.092 & 0.005 & 0.014 & 0.008 & 0.006 & 0.072 \\
\hline $\operatorname{ATG} S / S(E u)-(2)$ & $3 \mathrm{~d}: 10$ & 0.009 & 0.009 & 0.008 & 0.01 & 0.079 & 0 & 0.005 & 0.006 & 0.007 & 0.039 & 0.015 & 0.013 & 0.009 & 0.011 & 0.105 \\
\hline ATG S/S (Eu)-(3) & $7 \mathrm{~d}: 10$ & 0.013 & 0.012 & 0.017 & 0.015 & 0.125 & 0.004 & 0.006 & 0.006 & 0.007 & 0.050 & 0 & 0.004 & 0.004 & 0.003 & 0.024 \\
\hline Average & & & & & & 0.088 & & & & & 0.061 & & & & & 0.067 \\
\hline $\mathrm{Sx}$ & & & & & & 0.037 & & & & & 0.028 & & & & & 0.040 \\
\hline Error & & & & & & 0.02 & & & & & 0.02 & & & & & 0.03 \\
\hline NFS S/S (Am)-(1) & $1 \mathrm{~d}: 10$ & 0 & 0 & 0.007 & 0.012 & 0.042 & 0 & 0.003 & 0.004 & 0 & 0.015 & 0 & 0 & 0 & 0 & 0.000 \\
\hline NFS S/S (Am)-(2) & $3 \mathrm{~d}: 10$ & 0.004 & 0.01 & 0.008 & 0.01 & 0.070 & 0 & 0 & 0 & 0 & 0.000 & 0 & 0 & 0 & 0 & 0.000 \\
\hline NFS S/S (Am)-(3) & $7 \mathrm{~d}: 10$ & 0 & 0.003 & 0.007 & 0.009 & 0.042 & 0 & 0 & 0 & 0 & 0.000 & 0 & 0 & 0 & 0 & 0.000 \\
\hline Average & & & & & & 0.051 & & & & & 0.005 & & & & & 0.000 \\
\hline Sx & & & & & & 0.036 & & & & & 0.012 & & & & & 0.000 \\
\hline Error & & & & & & 0.02 & & & & & 0.01 & & & & & 0. \\
\hline
\end{tabular}


Table A-3. Summary of data for the samples maintained at $60^{\circ} \mathrm{C}$

\begin{tabular}{|c|c|c|c|c|c|c|c|c|c|c|c|c|c|c|c|c|}
\hline $\begin{array}{l}\text { Sample } \\
\text { name }\end{array}$ & $\begin{array}{l}\text { Size } \\
(\mathrm{mL})\end{array}$ & & $\begin{array}{l}1 \text { day - } \\
\text { read }\end{array}$ & $\begin{array}{l}05 / 09 / 00 \\
\text { ings }\end{array}$ & & $\begin{array}{c}{[\mathrm{Hg}]} \\
\left(\mathrm{mg} / \mathrm{m}^{3}\right)\end{array}$ & & $\begin{array}{r}3 \text { days - } \\
\text { reac }\end{array}$ & $\begin{array}{l}05 / 11 / 0 \\
\text { ings }\end{array}$ & & $\begin{array}{c}{[\mathrm{Hg}]} \\
\left(\mathrm{mg} / \mathrm{m}^{3}\right)\end{array}$ & & $\begin{array}{l}7 \text { days - } \\
\text { read }\end{array}$ & $\begin{array}{l}05 / 15 / 0 \\
\text { ings }\end{array}$ & & $\begin{array}{c}{[\mathrm{Hg}]} \\
\left(\mathrm{mg} / \mathrm{m}^{3}\right)\end{array}$ \\
\hline Blank -A (1) & $1 \mathrm{~d}: 1$ & 0.006 & 0 & 0 & 0 & 0.131 & 0.007 & 0.004 & 0.003 & 0.003 & 0.186 & 0 & 0 & 0 & 0 & 0.000 \\
\hline Blank- A (2) & $3 \mathrm{~d}: 2$ & 0.009 & 0.006 & 0.011 & 0.005 & 0.678 & 0.007 & 0.008 & 0.005 & 0.005 & 0.273 & 0 & 0 & 0 & 0 & 0.000 \\
\hline Blank-A (3) & $7 \mathrm{~d}: 2$ & 0.011 & 0.011 & 0.012 & 0.013 & 1.028 & 0.005 & 0.004 & 0.005 & 0.004 & 0.197 & 0 & 0 & 0 & 0 & 0.000 \\
\hline Average & & & & & & 0.61 & & & & & 0.22 & & & & & 0.00 \\
\hline Sx & & & & & & 0.412 & & & & & 0.067 & & & & & 0.000 \\
\hline Error & & & & & & 0.26 & & & & & 0.04 & & & & & 0.00 \\
\hline Mercury standard A (1) & $1 \mathrm{~d}: 0.3$ & 0.456 & 0.441 & 0.458 & 0.501 & 135.33 & 0.533 & 0.569 & 0.545 & 0.513 & 236.3 & 0.492 & 0.484 & 0.422 & 0.403 & 197.0 \\
\hline Mèrcury standard A (2) & $3 \mathrm{~d}: 0.2$ & 0.412 & 0.464 & 0.5 & 0.567 & 141.68 & 0.433 & 0.456 & 0.409 & 0.397 & 185.4 & 0.307 & 0.253 & 0.31 & 0.256 & 123.2 \\
\hline Mercury standard A (3) & $7 \mathrm{~d}: 0.2$ & 0.462 & 0.525 & 0.484 & 0.493 & 143.21 & 0.343 & 0.325 & 0.34 & 0.386 & 152.5 & 0.312 & 0.401 & 0.386 & 0.271 & 149.8 \\
\hline Average & & & & & & 140 & & & & & 191 & & & & & 157 \\
\hline Sx & & & & & & 11.422 & & & & & 35.773 & & & & & 35.409 \\
\hline Error & & & & - & & 7 & & & & & 23 & & & & $\therefore$ & 22 \\
\hline Untreated soil ATG(Eu)-(1) & $1 \mathrm{~d}: 0.3$ & 0.499 & 0.501 & 0.504 & 0.488 & 145.25 & 0.442 & 0.386 & 0.415 & 0.428 & 182.8 & 0.532 & 0.518 & 0.452 & 0.449 & 213.4 \\
\hline Untreated soil ATG(Eu)-(2) & $3 \mathrm{~d}: 0.2$ & 0.45 & 0.459 & 0.469 & 0.45 & 133.29 & 0.333 & 0.332 & 0.361 & 0.379 & 153.7 & 0.381 & 0.337 & 0.341 & 0.299 & 148.5 \\
\hline Untreated soil ATG(Eu)-(3) & $7 \mathrm{~d}: 0.2$ & 0.588 & 0.501 & 0.594 & 0.59 & 165.74 & 0.319 & 0.329 & 0.342 & 0.319 & 143.2 & 0.301 & 0.298 & 0.278 & 0.273 & 125.8 \\
\hline Average & & & & & & 148 & & & & & 160 & & & & & 163 \\
\hline $\mathrm{Sx}$ & & & & & & 15.006 & & & & & 18.397 & & & & & 39.130 \\
\hline Error & & & & & & 10 & & & & & 12 & & & & & 25 \\
\hline Untreated soil BNL(Am)-(1) & $1 \mathrm{~d}: 0.3$ & 0.303 & 0.345 & 0.359 & 0.348 & 98.80 & 0.31 & 0.234 & 0.255 & 0.231 & 112.7 & 0.366 & 0.334 & 0.317 & 0.305 & 144.6 \\
\hline Untreated soil BNL(Am)-(2) & $3 \mathrm{~d}: 0.2$ & 0.302 & 0.317 & 0.378 & 0.403 & 102.08 & 0.226 & 0.275 & 0.277 & 0.251 & 112.5 & 0.301 & 0.283 & 0.251 & 0.258 & 119.5 \\
\hline Untreated soil BNL(Am)-(3) & $7 \mathrm{~d}: 0.2$ & 0.335 & 0.35 & 0.321 & 0.373 & 100.55 & 0.238 & 0.25 & 0.244 & 0.259 & 108.4 & 0.252 & 0.227 & 0.215 & 0.195 & 97.2 \\
\hline Average & & & & & & 100 & & & & & 111 & & & & & 120 \\
\hline Sx & & & & & & 8.643 & & & & & 9.965 & & & & & 21.456 \\
\hline Error & & & & & & 5 & & & & & 6 & & & & & 14 \\
\hline
\end{tabular}


Table A-3 (cont.)

\begin{tabular}{|c|c|c|c|c|c|c|c|c|c|c|c|c|c|c|c|c|}
\hline \multirow{2}{*}{\begin{tabular}{|l|}
$\begin{array}{l}\text { Sample } \\
\text { name }\end{array}$ \\
Untreated soil NFS(Am)-(1)
\end{tabular}} & \multicolumn{2}{|l|}{$\begin{array}{l}\text { Size } \\
(\mathrm{mL})\end{array}$} & \multicolumn{3}{|c|}{$\begin{array}{l}1 \text { day }-05 / 09 / 00 \\
\text { readings }\end{array}$} & \multirow{2}{*}{$\frac{\begin{array}{c}{[\mathrm{Hg}]} \\
\left(\mathrm{mg} / \mathrm{m}^{3}\right)\end{array}}{104.71}$} & \multicolumn{4}{|c|}{$\begin{array}{c}3 \text { days }-05 / 11 / 00 \\
\text { readings }\end{array}$} & \multicolumn{2}{|c|}{$\begin{array}{c}{[\mathrm{Hg}]} \\
\left(\mathrm{mg} / \mathrm{m}^{3}\right)\end{array}$} & \multicolumn{3}{|c|}{$\begin{array}{l}7 \text { days }-05 / 15 / 00 \\
\text { readings }\end{array}$} & \multirow{2}{*}{$\frac{\begin{array}{c}{[\mathrm{Hg}]} \\
\left(\mathrm{mg} / \mathrm{m}^{3}\right)\end{array}}{155.1}$} \\
\hline & $1 \mathrm{~d}: 0.3$ & 0.357 & 0.356 & 0.386 & 0.337 & & 0.262 & 0.282 & 0.297 & 0.318 & 126.8 & 0.38 & 0.36 & 0.349 & 0.329 & \\
\hline Untreated soil NFS $(\Lambda \mathrm{m})-(2)$ & $3 \mathrm{~d}: 0.2$ & 0.438 & 0.423 & 0.414 & 0.454 & 126.07 & 0.296 & 0.287 & 0.301 & 0.314 & 131.0 & 0.318 & 0.334 & 0.319 & 0.309 & 140.0 \\
\hline Untreated soil NFS(Am)-(3) & $7 \mathrm{~d}: 0.2$ & 0.36 & 0.357 & 0.272 & 0.244 & 89.91 & 0.25 & 0.231 & 0.236 & 0.247 & 105.4 & 0.241 & 0.249 & 0.234 & 0.249 & 106.4 \\
\hline Average & & & & & & 107 & & & & & 121 & & & & & 134 \\
\hline $\mathrm{Sx}$ & & & & & & 17.608 & & & & & 12.73 & & & & & 21.051 \\
\hline Error & & & & & & 11 & & & & & 8 & & & & & 13 \\
\hline Untreated soil BNL(Eu)-(1) & $1 \mathrm{~d}: 0.3$ & 0.464 & 0.46 & 0.515 & 0.462 & 138.61 & 0.388 & 0.396 & 0.382 & 0.328 & 163.4 & 0.376 & 0.36 & 0.349 & 0.365 & 158.6 \\
\hline Untreated soil BNL(Eu)-(2) & $3 \mathrm{~d}: 0.2$ & 0.574 & 0.555 & 0.559 & 0.45 & 155.90 & 0.373 & 0.354 & 0.346 & 0.337 & 154.2 & 0.313 & 0.318 & 0.3 & 0.273 & 131.7 \\
\hline Untreated soil BNL(Eu)-(3) & $7 \mathrm{~d}: 0.2$ & 0.408 & 0.408 & 0.391 & 0.44 & 120.09 & 0.294 & 0.286 & 0.297 & 0.284 & 127.0 & 0.678 & 0.576 & 0.509 & 0.436 & 240.5 \\
\hline Average & & & & & & 138 & & & & & 148 & & & & & 177 \\
\hline Sx & & & & & & 17.508 & & & & & 17.26 & & & & & 51.708 \\
\hline Error & & & & & & 11 & & & & & 11 & & & & & 33 \\
\hline SepraDyne (Am) - (1) & $1 \mathrm{~d}: 1$ & 0.009 & 0.003 & 0.004 & 0.004 & 0.438 & 0 & 0 & 0 & 0.004 & 0.044 & 0.005 & 0.004 & 0 & 0.009 & 0.197 \\
\hline SepraDyne (Am) - (2) & $3 \mathrm{~d}: 2$ & 0.01 & 0 & 0 & 0 & 0.219 & 0.004 & 0.009 & 0.005 & 0 & 0.197 & 0.009 & 0.006 & 0.005 & 0.004 & 0.263 \\
\hline SepraDyne (Am) - (3) & $7 \mathrm{~d}: 2$ & 0 & 0 & 0 & 0 & 0.000 & 0.007 & 0.004 & 0.008 & 0.008 & 0.295 & 0.007 & 0.007 & 0.007 & 0.006 & 0.295 \\
\hline Average & & & & & & 0.22 & & & & & 0.18 & & & & & 0.25 \\
\hline Sx & & & & & & 0.306 & & & & & 0.145 & & & & & 0.103 \\
\hline Error & & & & & & 0.19 & & & & & 0.09 & & & & & 0.07 \\
\hline SepraDyne (Eu) - (1) & $1 \mathrm{~d}: 1$ & 0 & 0 & 0 & 0 & 0.000 & 0.009 & 0.004 & 0.004 & 0.005 & 0.241 & 0.005 & 0.008 & 0.008 & 0.004 & 0.273 \\
\hline SepraDyne (Eu) - (2) & $3 \mathrm{~d}: 2$ & 0 & 0.007 & 0 & 0.009 & 0.350 & 0.005 & 0.004 & 0.005 & 0.005 & 0.208 & 0.009 & 0.007 & 0.006 & 0.007 & 0.317 \\
\hline SepraDyne (Eu) - (3) & $7 \mathrm{~d}: 2$ & 0 & 0 & 0.005 & 0.008 & 0.284 & 0.005 & 0.006 & 0.006 & 0.004 & 0.230 & 0.005 & 0.004 & 0.004 & 0.004 & 0.186 \\
\hline Average & & & & & & 0.21 & & & & & 0.23 & & & & & 0.26 \\
\hline Sx & & & & & & 0.308 & & & & & 0.059 & & & & & 0.077 \\
\hline Error & & & & & & 0.20 & & & & & 0.04 & & & & & 0.05 \\
\hline
\end{tabular}


Table A-3 (cont.)

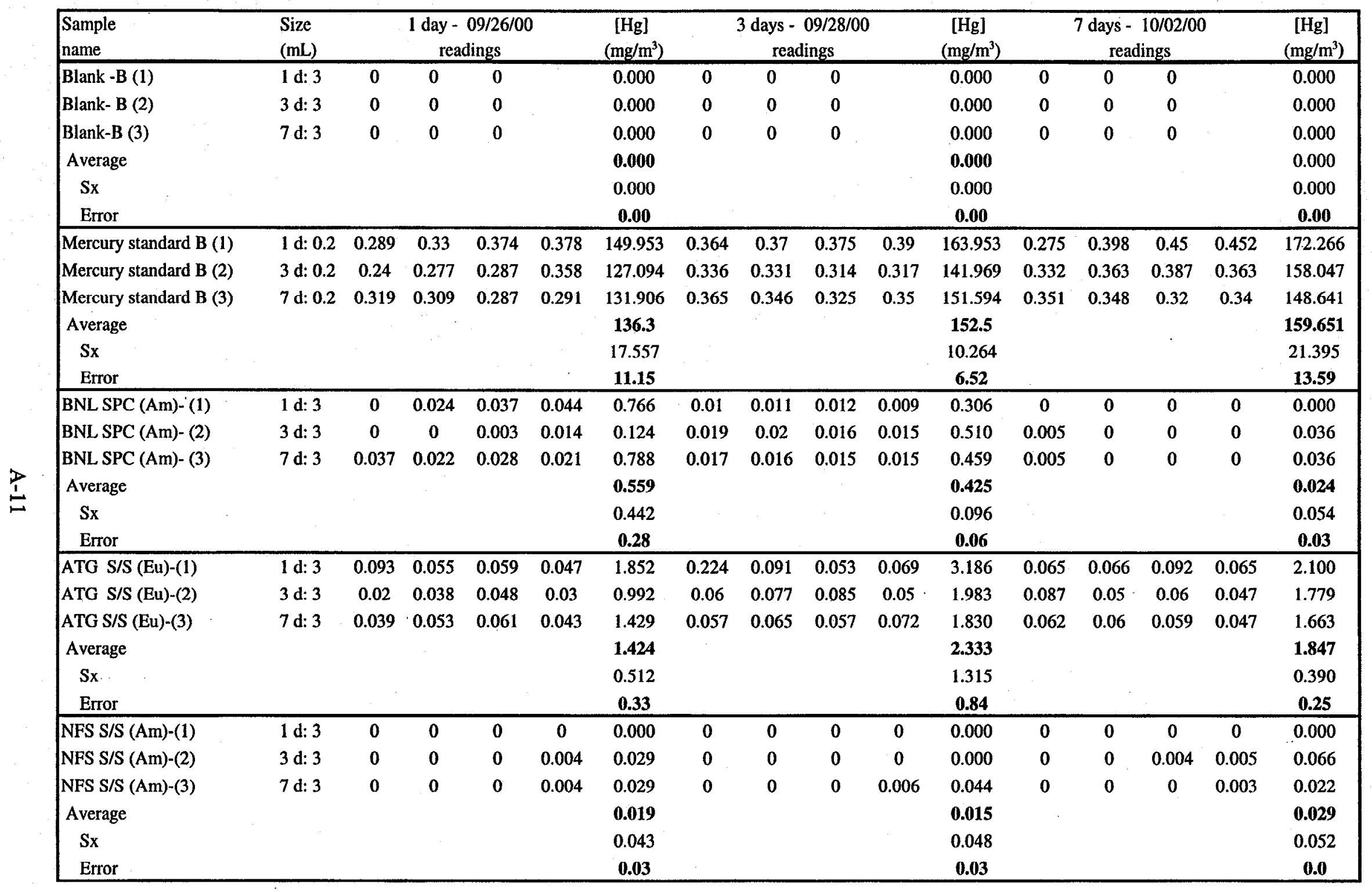




\section{INTERNAL DISTRIBUTION}

1. T. B. Conley

2. R. T. Jubin

3. C. M. Kendrick

4. P. Kirk

5. K. T. Klasson

6-10. C. H. Mattus

11. L. E. McNeese

12-13. M. I. Morris

14. S. M. Robinson

15. R. D. Spence

16. Central Research Library

17. Laboratory Records - RC

18-19. Laboratory Records - for submission to OSTI

\section{EXTERNAL DISTRIBUTION}

20. John Austin, U.S. EPA, OSW/5302W, 401 M Street, Washington, DC 20460

21. Mary Cunningham, U.S. EPA, OSW/5302W, 401 M Street, Washington, DC 20460

22. Ron Fontana, DOE-Idaho Operations, 850 Energy Drive, Idaho Falls, ID 83401-1235

23. G. A. Hulet, Idaho National Engineering and Environmental Laboratory, 2525 N. Freemont, Idaho Falls, ID 83415-3875

24. D. A. Hutchins, U.S. DOE, 55 Jefferson Avenue, MS-EW97, Oak Ridge, TN 37830

25. N. Jacobs, Nuclear Fuel Services, 1205 Banner Hill Road, Erwin, TN 37650

26. Paul Kalb, Brookhaven National Laboratory, 34 North Railroad St, Upton, NY 11973

27. David S. Kosson, Vanderbilt University, Box 1831 Station B, Nashville, TN 37235

28. Josh Lewis, U.S. EPA, OSW/5302W, 401 M Street, Washington, DC 20460

29. Bill Ocwa, DOE-Idaho Operations, 2525 N. Freemont, Idaho Falls, ID 83415-3875

30. Lynn Schwendiman, DOE-Idaho Operations, 2525 N. Freemont, Idaho Falls, ID 83415-3875

31. R. Eric Williams, Idaho National Engineering and Environmental Laboratory, 2525 N. Freemont, Idaho Falls, ID 83415-3875

32. William Smith, ATG, 47375 Fremont Blvd., Fremont, CA 94538

33. David Maknius, SepraDyne Corp., 12801 Stemmons Frwy, Suite 803, Farmers Branch, TX 75234. 
s

ร

. 